Quim. Nova, Vol. 35, No. 8, 1570-1576, 2012

\title{
ent-KAURANE DITERPENOIDS AND OTHER CONSTITUENTS FROM THE STEM OF Xylopia laevigata
} (Annonaceae)

\author{
Dayanne Meneses Silva, Emmanoel Vilaça Costa*, Paulo Cesar de Lima Nogueira e Valéria Regina de Souza Moraes \\ Departamento de Química, Universidade Federal de Sergipe, Av. Mal. Rondon, s/n, 49100-000 São Cristóvão - SE, Brasil \\ Sócrates Cabral de Holanda Cavalcanti \\ Departamento de Farmácia, Universidade Federal de Sergipe, Av. Mal. Rondon, s/n, 49100-000 São Cristóvão - SE, Brasil \\ Marcos José Salvador \\ Curso de Farmácia, Departamento de Biologia Vegetal, Instituto de Biologia, Universidade Estadual de Campinas, CP 6109, \\ 13083-970 Campinas - SP, Brasil \\ Luis Henrique Gonzaga Ribeiro e Fernanda Ramos Gadelha \\ Departamento de Bioquímica, Instituto de Biologia, Universidade Estadual de Campinas, CP 6109, 13083-970 Campinas - SP, Brasil \\ Andersson Barison \\ Departamento de Química, Universidade Federal do Paraná, CP 19081, 81531-990 Curitiba - PR, Brasil \\ Antonio Gilberto Ferreira \\ Departamento de Química, Universidade Federal de São Carlos, CP 676, 13565-905 São Carlos - SP, Brasil
}

Recebido em 4/1/12; aceito em 14/3/12; publicado na web em 10/7/12

\begin{abstract}
Phytochemical investigation of the hexane extract from the stem of Xylopia laevigata led to the isolation of the ent-kaurane

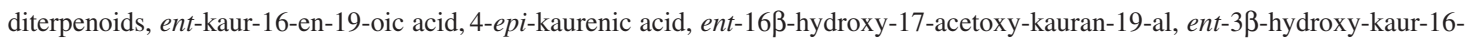
en-19-oic acid, and ent-16ß,17-dihydroxy-kauran-19-oic acid, as well as spathulenol and a mixture of $\beta$-sitosterol, stigmasterol and campesterol. The identification of the compounds was performed on the basis of spectrometric methods including GC-MS, IR, and

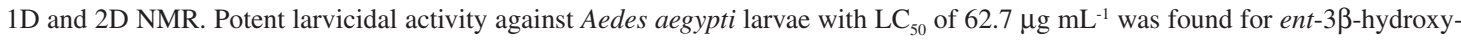
kaur-16-en-19-oic acid. This compound also showed significant antifungal activity against Candida glabrata and Candida dubliniensis with MIC values of $62.5 \mu \mathrm{g} \mathrm{mL} \mathrm{m}^{-1}$.
\end{abstract}

Keywords: Xylopia laevigata; ent-kaurane-diterpenes; larvicidal and antifungal properties.

\section{INTRODUCTION}

Xylopia L. (Annonaceae) comprises approximately 150 species of aromatic shrubs and trees, around 40 of which occur throughout tropical America. ${ }^{1}$ Some species of this genus, such as Xylopia aethiopica, $X$. serice $a$ and $X$. aromatica are used as condiments, as well as for medicinal purposes. ${ }^{2}$ Previous phytochemical investigations on some species of this genus have indicated the presence of terpenoids, ${ }^{3}$ alkaloids, ${ }^{4}$ and flavonoids, ${ }^{4}$ exhibiting several pharmacological activities such as antifungal, ${ }^{3}$ antioxidant, ${ }^{2,4}$ antileishmanial, ${ }^{5}$ cytotoxic, ${ }^{6}$ antinociceptive, ${ }^{7}$ acaricidal, ${ }^{8}$ and insecticidal properties. ${ }^{9}$ Xylopia laevigata (Mart.) R.E. Fries popularly known as "meiú" and "pindaíba" is a small tree endemic to Brazil found in the States of Paraíba, Piauí, Rio de Janeiro, São Paulo, and Sergipe. ${ }^{10}$ In Sergipe, it is found in remaining Atlantic forest, sandbank forests and coastal seaboards. Its leaves closely resemble those of some species of Oxandra. ${ }^{10}$

In our continuous search for natural products from Sergipe Annonaceous plants with trypanocidal, antifungal and antibacterial properties, as well as with larvicidal activity against Aedes aegypti larvae, herein we report the phytochemical investigation of the hexane extract from the stem of $X$. laevigata. To the best of our knowledge this is the first report on the phytochemical investigation and biological activities of this plant.

\section{RESULTS AND DISCUSSION}

Once hexane crude extract was found to have trypanocidal activity

*e-mail: emmanoelvc@gmail.com
$\left(\mathrm{IC}_{50}=866.0 \pm 12.7 \mu \mathrm{g} \mathrm{mL}^{-1}\right)$, antimicrobial action (Table 1), and larvicidal properties against Aedes aegypti larvae $\left(\mathrm{LC}_{50}=439.86\right.$ $\mu \mathrm{g} \mathrm{mL}^{-1}$ ), this extract was subjected to successive chromatographic techniques as described in the Experimental section leading to the isolation of nine chemical constituents: one sesquiterpene (1), a mixture of three steroids (2-4), and five ent-kaurane diterpenes (5-9) (Figure 1). All isolated compounds are described for the first time in this species.

Compounds 1-6 were identified by comparing their spectrometric data with those reported in the literature, namely: spathulenol (1), ${ }^{11}$ a mixture of $\beta$-sitosterol, (2), stigmasterol (3) and campesterol (4), ${ }^{12}$ ent-kaur-16-en-19-oic acid (5), ${ }^{13}$ and 4-epi-kaurenic acid (6). ${ }^{14}$ The ent-kaurane diterpenes are very common in Annonaceae, particularly in the species of Annona and Xylopia. ${ }^{15}$ In Xylopia, this class of compounds is well represented and considered as chemotaxonomic markers. Among them, compound $\mathbf{5}$ is the most representative within the Annonaceae family found predominantly in the Xylopia (such as $X$. aethiopica, $X$. frutescens and $X$. sericea), and Annona (such as A. cherimola, A. glabra, A. senegalensis, and A. squamosa). ${ }^{13,15}$ Compound 6 has been described only in Mitrephora glabra also belonging to the Annonaceae family. ${ }^{14}$ Therefore, the presence of ent-kaurane diterpenes in $X$. laevigata confirms that this species is typical of the Annonaceae family.

Compound 7 was obtained as white needles with the molecular formula, $\mathrm{C}_{22} \mathrm{H}_{34} \mathrm{O}_{4}$, as determined by GC-MS and NMR data. The ${ }^{1} \mathrm{H}$ NMR spectrum showed signals for two tertiary methyl groups at $\delta 0.87$ and 0.99 ( $3 \mathrm{H}$ each), that are typical of equatorial $\mathrm{C}-18$ and axial C-20 methyl groups of ent-kaurane diterpenes with a C-19 axial aldehyde group. The spectrum exhibited a signal for an 


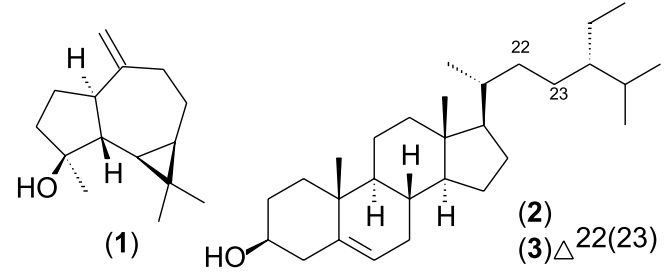<smiles>CC(C)CCCC(C)[C@H]1CC[C@H]2[C@@H]3CC=C4CC(O)CCC4(C)C3CCC21C</smiles>

(5) $\mathrm{R}=\mathrm{H}$

(8) $\mathrm{R}=\mathrm{OH}$

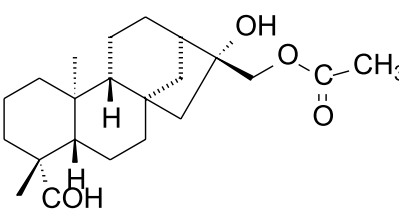

(7)

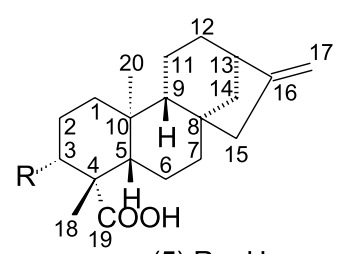

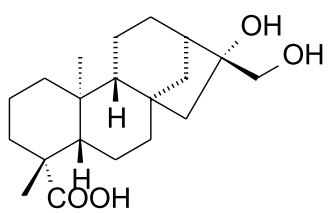

(9)
Figure 1. ent-Kaurane diterpenoids and other constituents from the stem of Xylopia laevigata aldehyde group at $\delta 9.74(1 \mathrm{H}, d 1.3 \mathrm{~Hz}) \cdot{ }^{13}$ The ${ }^{1} \mathrm{H}-{ }^{1} \mathrm{H}-\mathrm{COSY}$ NMR experiment revealed that the aldehyde hydrogen was coupling with one of $\mathrm{H}-3$ at $\delta 0.99$, probably due to a "W" orientation, supporting the equatorial C-18 and axial C-19 configurations. The other major feature in the ${ }^{1} \mathrm{H}$ NMR spectrum of 7 was an AB quartet $(2 \mathrm{H})$ with doublets centered at $\delta 4.24$ and $4.21(J 11.6 \mathrm{~Hz})$, and a singlet at $\delta 2.10(3 \mathrm{H})$ indicating the presence of an oxygenated exocyclic methylene and an acetate group in the structure of 7 . The ${ }^{13} \mathrm{C}\left\{{ }^{1} \mathrm{H}\right\}$ and DEPT 135 NMR spectra, as well as one-bond and long-range ${ }^{1} \mathrm{H}-{ }^{13} \mathrm{C}$ correlation maps from HSQC and HMBC NMR experiments indicated a total of 22 carbons (Table 2). These carbons comprised three methyl, eleven methylenes (including an acetoxy-bearing carbon at $\delta 68.4$ ), three methines, four quaternary carbons (including an oxygenated carbon at $\delta 79.9$ and an ester carbonyl at $\delta$ 171.2), and one aldehyde carbon at $\delta$ 205.8. Comparison of ${ }^{1} \mathrm{H}$ and ${ }^{13} \mathrm{C}$ NMR data with those reported for the kaurane diterpene 16ß,17-dihydroxykauran-19-al suggested that compound 7 has the same ent-kaurane-type skeleton. ${ }^{13}$ The acetate group in the structure at $\mathrm{C}-17$ was confirmed by ${ }^{1} \mathrm{H}-{ }^{13} \mathrm{C}$ long-range correlation mao from the HMBC NMR experiment. A correlation was observed in this between both the hydrogens at $\delta 4.24$ and 4.21 (H-17) and the carbons at $\delta 171.2$ (ester carbonyl group), 45.9 (C-13), 52.8 (C-15), and $79.9(\mathrm{C}-16)$, as well as correlation of the methyl hydrogens at $\delta 2.10$ and the same ester carbonyl group at $\delta 171.2$. Similarly, the aldehyde group at C-19 was established on the basis of HMBC NMR experiments, since correlation was observed between the hydrogen at $\delta 9.74(\mathrm{H}-19)$ and the carbons at $\delta 34.2(\mathrm{C}-3)$, and 48.4 (C-4). The ent series configuration and the $16 \beta$ orientation were supported by $1 \mathrm{D}$ NOE NMR selective experiments. The selective irradiation of the resonance frequency of the $\mathrm{H}-18$ at $\delta 0.99$ caused a NOE enhancement in the signals at $\delta 2.13$ (H-3ax), 1.88 (H-6eq) and 1.14 (H-5), but any intensification of the signal from $\mathrm{H}-20$ at $\delta$ 0.87. Selective irradiation of the resonance frequency of the hydrogen $\mathrm{H}-19$ at $\delta 9.74$ showed a NOE intensification of the

Table 1. Antifungal and antibacterial activities of the crude extracts and ent-kaurane diterpenoids $\mathbf{5}, \mathbf{8}$, and $\mathbf{9}$

\begin{tabular}{|c|c|c|c|c|c|c|}
\hline \multirow{2}{*}{ Microorganism } & \multicolumn{6}{|c|}{$\mathrm{MIC}^{\mathrm{a}}\left(\mu \mathrm{g} \mathrm{mL} \mathrm{L}^{-1}\right)$} \\
\hline & Hexane extract & Methanolic extract & 5 & 8 & 9 & Positive controls $^{b}$ \\
\hline Candida albicans (ATCC 10231) ${ }^{c}$ & 1000 & 500 & $>500$ & $>500$ & $>500$ & 12.5 \\
\hline Candida albicans (ATCC 1023) & $-\mathrm{e}$ & 5000 & $>500$ & $>500$ & $>500$ & 12.5 \\
\hline Candida parapsilosis (ATCC 22019) & f & f & $>500$ & $>500$ & $>500$ & 12.5 \\
\hline Candida tropicalis (ATCC 157) ${ }^{\mathrm{c}}$ & 1000 & 5000 & $>500$ & $>500$ & 250 & 12.5 \\
\hline Candida tropicalis $(\mathrm{CT})^{\mathrm{d}}$ & 1000 & 5000 & $>500$ & $>500$ & $>500$ & 12.5 \\
\hline Candida glabrata $(\mathrm{ATCC} 30070)^{\mathrm{c}}$ & 500 & 500 & 125 & 62.5 & 250 & 12.5 \\
\hline Candida dubliniensis (ATCC 778157) ${ }^{\mathrm{c}}$ & 500 & 5000 & 125 & 62.5 & 250 & 12.5 \\
\hline Bacillus subtilis $(\mathrm{Bs})^{\mathrm{d}}$ & 1000 & 1000 & - & - & - & 50 \\
\hline Enterobacter aerogenes $(\mathrm{Ea})^{\mathrm{d}}$ & 500 & - & - & - & - & 50 \\
\hline Escherichia coli $(\mathrm{ATCC} 10538)^{\mathrm{c}}$ & 1000 & - & - & $>500$ & - & 50 \\
\hline Escherichia coli (ATCC 10799) ${ }^{\mathrm{c}}$ & 500 & - & - & $>500$ & - & 50 \\
\hline Proteus vulgaris $(\mathrm{Pv})^{\mathrm{d}}$ & 500 & 1000 & $>500$ & 250 & - & 50 \\
\hline Pseudomonas aeruginosa $\left(\right.$ ATCC 27853) ${ }^{c}$ & - & - & & - & - & 850 \\
\hline Staphylococcus aureus (ATCC14458) ${ }^{\mathrm{C}}$ & 1000 & 1000 & - & 125 & - & 25 \\
\hline Staphylococcus aureus (ATCC6538) ${ }^{c}$ & 500 & - & - & 125 & - & 25 \\
\hline Staphylococcus epidermidis (ATCC 1228) ${ }^{\mathrm{c}}$ & 500 & 1000 & - & 500 & - & 50 \\
\hline Staphylococcus epidermidis (6epi) ${ }^{\mathrm{d}}$ & 500 & 1000 & - & 500 & - & 50 \\
\hline
\end{tabular}

${ }^{\mathrm{a}} \mathrm{MIC}$ (minimum inhibitory concentration) in $\mu \mathrm{g} \mathrm{mL}{ }^{-1}$; ${ }^{\mathrm{b}}$ positive controls (chloramphenicol for bacteria strains and ketoconazole for yeast strains); ${ }^{\mathrm{s}}$ standard strain; ${ }^{\mathrm{d}}$ ield strain; ${ }^{\mathrm{e}}(-)$ no inhibition of development; ${ }^{\mathrm{f}}$ not evaluated. 
Table 2. ${ }^{1} \mathrm{H}$ and ${ }^{13} \mathrm{C}$ NMR data (400 MHz) for ent-kaurane diterpenoids 7-9

\begin{tabular}{|c|c|c|c|c|c|c|}
\hline \multirow{2}{*}{ Position } & \multicolumn{2}{|r|}{7} & \multicolumn{2}{|r|}{8} & \multicolumn{2}{|r|}{9} \\
\hline & $\delta_{\mathrm{C}}{ }^{a}$ & $\delta_{\mathrm{H}}$ mult. $(J \text { in } \mathrm{Hz})^{\mathrm{a}}$ & $\delta_{\mathrm{C}}{ }^{\mathrm{b}}$ & $\delta_{\mathrm{H}}$ mult. $(J \text { in } \mathrm{Hz})^{\mathrm{b}}$ & $\delta_{\mathrm{C}}{ }^{\mathrm{b}}$ & $\delta_{\mathrm{H}}$ mult. $(J \text { in } \mathrm{Hz})^{\mathrm{b}}$ \\
\hline 1 & 41.7 & $\begin{array}{l}1.50 \mathrm{~m} \\
1.72 \mathrm{~m}\end{array}$ & 39.4 & $\begin{array}{l}1.95 \mathrm{~m} \\
0.93 \mathrm{~m}\end{array}$ & 40.9 & $\begin{array}{l}1.84 \mathrm{~m} \\
0.80 \mathrm{~m}\end{array}$ \\
\hline 2 & 18.3 & $\begin{array}{l}1.45 \mathrm{~m} \\
1.60 \mathrm{~m}\end{array}$ & 28.1 & $\begin{array}{l}1.75 \mathrm{~m} \\
2.02 \mathrm{~m}\end{array}$ & 19.3 & $\begin{array}{l}1.42 \mathrm{~m} \\
1.88 \mathrm{~m}\end{array}$ \\
\hline 3 & 34.2 & $\begin{array}{c}2.13 \mathrm{dm}(13.4) \\
0.99 \mathrm{~m}\end{array}$ & 78.1 & $3.10 d d(11.9$ and 4.5$)$ & 38.2 & $\begin{array}{c}2.14 \mathrm{dm}(13.5) \\
1.00 \mathrm{~m}\end{array}$ \\
\hline 4 & 48.4 & & 48.4 & & 43.8 & \\
\hline 5 & 56.5 & $1.14 d d(12.5$ and 2.0$)$ & 56.3 & $0.94 m$ & 57.0 & $1.05 \mathrm{~m}$ \\
\hline 6 & 20.0 & $\begin{array}{l}1.88 \mathrm{~m} \\
1.69 \mathrm{~m}\end{array}$ & 21.7 & $\begin{array}{l}1.84 \mathrm{~m} \\
1.74 \mathrm{~m}\end{array}$ & 22.3 & $\begin{array}{l}1.84 \mathrm{~m} \\
1.70 \mathrm{~m}\end{array}$ \\
\hline 7 & 39.6 & $\begin{array}{c}0.78 \mathrm{~m} \\
1.80 \mathrm{dm}(13.1)\end{array}$ & 41.2 & $\begin{array}{l}1.43 \mathrm{~m} \\
1.54 \mathrm{~m}\end{array}$ & 42.2 & $\begin{array}{l}1.45 \mathrm{~m} \\
1.63 \mathrm{~m}\end{array}$ \\
\hline 8 & 44.6 & & 44.0 & & 44.8 & \\
\hline 9 & 55.1 & $1.02 \mathrm{~m}$ & 55.0 & $1.03 \mathrm{~m}$ & 56.1 & $1.00 \mathrm{~m}$ \\
\hline 10 & 39.3 & & 39.2 & & 39.8 & \\
\hline 11 & 18.3 & $\begin{array}{l}1.45 \mathrm{~m} \\
1.60 \mathrm{~m}\end{array}$ & 18.5 & $\begin{array}{l}1.54 \mathrm{~m} \\
1.61 \mathrm{~m}\end{array}$ & 18.7 & $\begin{array}{l}1.51 \mathrm{~m} \\
1.60 \mathrm{~m}\end{array}$ \\
\hline 12 & 26.0 & $\begin{array}{l}1.50 \mathrm{~m} \\
1.58 \mathrm{~m}\end{array}$ & 33.0 & $\begin{array}{l}1.47 \mathrm{~m} \\
1.61 \mathrm{~m}\end{array}$ & 26.3 & $\begin{array}{l}1.51 \mathrm{~m} \\
1.59 \mathrm{~m}\end{array}$ \\
\hline 13 & 45.9 & $2.05 \mathrm{~m}$ & 43.8 & $2.64 m$ & 45.2 & $2.01 \mathrm{~m}$ \\
\hline 14 & 37.2 & $\begin{array}{l}1.67 \mathrm{~m} \\
1.91 \mathrm{~m}\end{array}$ & 39.6 & $\begin{array}{c}1.14 d d(11.3 \text { and } 5.0) \\
1.97 \mathrm{~m}\end{array}$ & 37.3 & $\begin{array}{l}1.62 \mathrm{~m} \\
1.94 \mathrm{~m}\end{array}$ \\
\hline 15 & 52.8 & $\begin{array}{l}1.51 \mathrm{~m} \\
1.59 \mathrm{~m}\end{array}$ & 48.7 & $\begin{array}{l}1.97 \mathrm{~m} \\
2.05 \mathrm{~m}\end{array}$ & 52.8 & $\begin{array}{l}1.41 \mathrm{~m} \\
1.53 \mathrm{~m}\end{array}$ \\
\hline 16 & 79.9 & & 155.7 & & 82.1 & \\
\hline 17 & 68.4 & $\begin{array}{l}4.24 d(11.6) \\
4.21 d(11.6)\end{array}$ & 103.1 & $\begin{array}{l}4.74 s \\
4.80 s\end{array}$ & 66.1 & $\begin{array}{l}3.61 d(11.2) \\
3.73 d(11.2)\end{array}$ \\
\hline 18 & 24.2 & $0.99 s$ & 24.0 & $1.40 \mathrm{~s}$ & 29.1 & $1.19 s$ \\
\hline 19 & 205.8 & $9.74 d(1.3)$ & 180.8 & & 180.9 & \\
\hline 20 & 16.4 & $0.87 s$ & 15.7 & $0.98 s$ & 15.6 & $0.95 s$ \\
\hline $\mathrm{CH}_{3} \mathrm{COO}$ & 171.2 & & & & & \\
\hline $\mathrm{CH}_{3} \mathrm{COO}$ & 20.9 & $2.10 \mathrm{~s}$ & & & & \\
\hline
\end{tabular}

The experiments were obtained at $293 \mathrm{~K}_{\text {in }}{ }^{\mathrm{a}} \mathrm{CDCl}_{3}$ or ${ }^{\mathrm{b}} \mathrm{CDCl}_{3}+$ drops of $\mathrm{CD}_{3} \mathrm{OD}$.

signals at $\delta 0.87$ (H-20) and 1.69 (H-6ax), but no enhancement of the signal from $\mathrm{H}-5$ at $\delta 1.14$. Moreover, the selective irradiation of the resonance frequencies of both $\mathrm{H}-17$ at $\delta 4.24$ and 4.21 caused NOE enhancements in the signals at $\delta 1.50$ (H-12ax), and both $\mathrm{H}-15$ at $\delta 1.51$ and 1.59 , but no intensification of the signals at $\delta 1.67$ and 1.91 (H-14). The overall analysis of $1 \mathrm{D}$ and 2D NMR experiments enabled the structure to be fully elucidated, as well as to perform the complete and unambiguous ${ }^{1} \mathrm{H}$ and ${ }^{13} \mathrm{C}$ NMR chemical shift assignments of 7 (Table 2). Therefore, compound 7 was identified as ent-16ß-hydroxy-17-acetoxy-kauran-19-al. This compound was previously isolated from fresh fruits of Annona squamosa and stems of Annona cherimola. ${ }^{13,15}$

Compound $\mathbf{8}$ was obtained as white crystalline powder with the molecular formula, $\mathrm{C}_{20} \mathrm{H}_{30} \mathrm{O}_{3}$, as determined by CG-MS, LRESIMS, and NMR data. The ${ }^{1} \mathrm{H}$ NMR spectrum revealed two methyl singlets at $\delta 1.40$ and 0.98 ( $3 \mathrm{H}$ each). Additionally, two singlets were observed at $\delta 4.74$ and 4.80 (1H each) typical of the hydrogens from an exocyclic double bond. According to the HSQC NMR experiment, these hydrogens are connected to the carbons at $\delta 24.0,15.7$ and 103.1, respectively (Table 2). All NMR data observed for $\mathbf{8}$ were very similar to those observed for the ent-kaur-16-en-19-oic acid (5), except for an additional signal for a carbinolic hydrogen at $\delta 3.10(1 \mathrm{H}, \mathrm{dd}, J 11.9$ and $4.5 \mathrm{~Hz}$ ), suggesting the presence of a very similar compound. A one-bond ${ }^{1} \mathrm{H}-{ }^{13} \mathrm{C}$ correlation between the hydrogen at $\delta 3.10$ and the carbon at $\delta 78.1$ was observed and ${ }^{1} \mathrm{H}-{ }^{13} \mathrm{C}$ long-range correlation from the HMBC NMR experiment between the hydrogen at $\delta 3.10$ and the carbons at $\delta 28.1$ (C-2), 48.4 (C-4), 24.0 (C-18) and 180.8 (C-19) was seen, indicating the presence of a hydroxyl group at C-3 in the structure of $\mathbf{8}$. Moreover, ${ }^{1} \mathrm{H}-{ }^{1} \mathrm{H}$ correlation was observed, from the COSY NMR experiment, only between the hydrogen at $\delta 3.10$ $(\mathrm{H}-3)$ and the hydrogens at $\delta 2.02$ and $\delta 1.75(\mathrm{H}-2)$, supporting the substitution at C-3. The overall analysis of 1D and 2D NMR data enabled the structure to be fully elucidated, as well as to perform the complete and unambiguous ${ }^{1} \mathrm{H}$ and ${ }^{13} \mathrm{C}$ NMR chemical shift assignments of $\mathbf{8}$ (Table 2). The $\beta$-orientation of the hydroxyl group at $\mathrm{C}-3$ was established by comparing the NMR data obtained in this work against those described in the literature for 3-hydroxy-kauranoic acids. Hydrogens at $\mathrm{C}-3$ in $\alpha$ and $\beta$ isomers are described as having ${ }^{1} \mathrm{H}$ NMR chemical shifts at $\delta 4.11$ and 3.14, respectively. ${ }^{16}$ Therefore, the ${ }^{1} \mathrm{H}$ NMR chemical shifts found in this work to $\mathrm{H}-3$ at $\delta 3.10$ are in accordance with a $\beta$ orientation. This fact was also supported by $1 \mathrm{D}$ NOE NMR selective experiments. In these, the selective irradiation of the resonance frequency of $\mathrm{H}-3$ at $\delta 3.10$ caused a NOE enhancement in the signals at $\delta 1.40(\mathrm{H}-18), 0.93$ (H-1ax) and 0.94 (H-5). Moreover, the selective irradiation of the resonance frequency of the methyl hydrogens $\mathrm{H}-18$ at $\delta 1.40$ showed a NOE intensification of the signals at $\delta 3.10(\mathrm{H}-3), 0.94(\mathrm{H}-5)$ and 1.84 (H-6eq), but no enhancement of the signal from $\mathrm{H}-20$ at $\delta 0.98$. Recently, Barrero et 
al. ${ }^{17}$ described the complete ${ }^{1} \mathrm{H}$ and ${ }^{13} \mathrm{C}$ NMR data for this compound as $3 \beta$, although according to Lunnon and MacMillan, ${ }^{16}$ and our findings using ${ }^{1} \mathrm{H}$ and ${ }^{13} \mathrm{C}, 1 \mathrm{D}$ and $2 \mathrm{D}$ NMR experiments the compound isolated by Barrero et al. ${ }^{17}$ was the $3 \alpha$ isomer. Moreover, our NMR data were in full accordance with those presented by Rezende et $a l .{ }^{18}$ reporting the isolation of ent-3 $\beta$-hydroxy-kaur-16-en-19-oic acid from Pseudognaphalium vira vira (Asteraceae) whose structure determination was supported by $\mathrm{X}$-ray diffraction analysis. Therefore, compound $\mathbf{8}$ was elucidated as ent-3ß-hydroxy-kaur-16-en-19-oic acid and is described for the first time in the Annonaceae family. This compound is frequently described as a product of biotransformation by microorganisms. ${ }^{16,17}$ As a natural product from plants, this compound has also been isolated from Pseudognaphalium cheirantifolium and $P$. heterotrichium (Asteraceae). ${ }^{18}$

Compound 9 was obtained as white powder with the molecular formula, $\mathrm{C}_{20} \mathrm{H}_{32} \mathrm{O}_{4}$, as determined by CG-MS, LRESIMS, and NMR data. The ${ }^{1} \mathrm{H}$ and ${ }^{13} \mathrm{C}$ NMR spectra of compound 9 were very similar to those of 7, excepting for the absence of the acetate and aldehyde groups, again suggesting the presence of an ent-kaurane diterpenetype structure. Its ${ }^{1} \mathrm{H}$ NMR spectrum displayed two methyl singlets at $\delta 1.19$ and 0.95 (3H each), and a pair of doublets at $\delta 3.73$ and 3.61 (1H each, $J 11.2 \mathrm{~Hz}$ ), indicating the presence of a hydroxylmethyl group at $\mathrm{C}-17$, replacing the acetate group in 7 . This finding was supported by the one-bond ${ }^{1} \mathrm{H}_{-}{ }^{13} \mathrm{C}$ correlation of the hydrogens at $\delta 3.73$ and $\delta 3.61$ and the same carbon at $\delta 66.1$ (C-17) according to the HSQC NMR experiment, and the $\mathrm{H}_{-}{ }^{13} \mathrm{C}$ long-range correlation between both hydrogens at $\delta 3.73$ and 3.61 and the carbons at $\delta 45.2$ (C-13), 52.8 (C-15), and 82.1 (C-16) - according to HMBC NMR experiment. All NMR data found for compound 9 were in accordance with those observed for 16,17-dihydroxy-kauranoic acids described in the literature. ${ }^{13,19}$ The stereochemistry of C-16 was established by comparing its ${ }^{13} \mathrm{C}$ NMR data with those from the literature reporting the chemical shifts for the $\alpha$ and $\beta$ 16,17-dihydroxy-kauranoic acid isomers. ${ }^{19}$ In the ent configuration, when the stereochemistry of $\mathrm{C}-16$ is $R$ or the hydroxyl group at C-16 and C-17 are in equatorial and axial positions, respectively ( $16 \alpha$ isomer), NMR chemical shifts around $\delta 79$ and 70 can be observed, respectively. However, when the stereochemistry of the C-16 is $S$, or the hydroxyl group at $\mathrm{C}-16$ and $\mathrm{C}-17$ are in axial and equatorial positions, respectively (16 $\beta$ isomer), they present NMR chemical shifts around $\delta 81$ and 66 , respectively. Since in this work ${ }^{13} \mathrm{C}$ NMR chemical shifts were observed at $\delta 82.1$ and 66.1 for $\mathrm{C}-16$ and $\mathrm{C}-17$, respectively (Table 2), the stereochemistry of compound 9 at C-16 was established as $S$, indicating the $16 \beta$ configuration. The overall analysis of $1 \mathrm{D}$ and $2 \mathrm{D}$ NMR experiments enabled the structure to be fully elucidated, as well as to perform the complete and unambiguous ${ }^{1} \mathrm{H}$ and ${ }^{13} \mathrm{C} N M R$ chemical shift assignments of $\mathbf{9}$ (Table 2). Thus, compound $\mathbf{9}$ was elucidated as ent-16ß,17-dihydroxy-kauran-19-oic acid.

According to Velandia et al. ${ }^{19}$ the absolute configurations of the diterpenoids of ent and normal series can be established on the basis of negative and positive values from its specific rotation $\left([\alpha]^{\mathrm{D}}\right)$, since they can be correlated with the defined absolute configurations for similar diterpenes of the same class of kauranoids. ${ }^{19}$ Therefore, the diterpenoids that divert the light polarized to the left (-) belong to the ent series, while those that divert the light polarized to the right $(+)$ belong to the normal series..$^{19}$ In this work, all diterpenoids isolated diverted the light polarized to the left (-) confirming the ent series.

In agreement with the work performed by Velandia et al. ${ }^{19}$ it was possible to confirm that the compound isolated by $\mathrm{Wu}$ et al..$^{13}$ was the $16 \alpha$-hydroxy-17-acetoxy-ent-kauran-19-al and not $16 \beta$-hydroxy17-acetoxy-ent-kauran-19-al as described by the authors. ${ }^{13}$ The ${ }^{13} \mathrm{C}$ NMR chemical shifts found for $\mathrm{C}-16$ and $\mathrm{C}-17$ were $\delta 78.6$ and $71.2,{ }^{13}$ respectively, indicating that the stereochemistry of C-16 is $R$ or the hydroxyl group at C-16 and the acetoxy group C-17 are in equatorial and axial positions, respectively ( $16 \alpha$ isomer). In this work, since ${ }^{13} \mathrm{C}$ NMR chemical shifts were observed at $\delta 79.9$ and 68.4 for C-16 and C-17, respectively (Table 2), the stereochemistry of compound 7 at C-16 was established as $S$, indicating the $16 \beta$ configuration.

Since the hexane extract showed trypanocidal activity $\left(\mathrm{IC}_{50}=\right.$ $866.0 \pm 12.7 \mu \mathrm{g} \mathrm{mL}^{-1}$ ) against epimastigote forms of $T$. cruzi the major compounds isolated 5-9 were also submitted to trypanocidal assay, although no activity up to concentrations of $1000 \mu \mathrm{g} \mathrm{mL}^{-1}$ was observed. The activity presented by the hexane extract is most likely attributed to synergistic action of the isolated compounds or other compounds present in the extract that was not isolated. For compound 5, Alves et al. ${ }^{20}$ have described its activity against trypomastigote forms of $T$. cruzi. However, the acid showed blood lytic activity in erythrocytes and also low solubility in the biological medium used for the test. In this study, no activity was observed for compound $\mathbf{5}$ against epimastigote forms of $T$. cruzi up tp the concentration tested. Benznidazole, a drug used in the treatment of Chagas' disease, showed an $\mathrm{IC}_{50}$ of $2.23 \pm 0.08 \mu \mathrm{M}\left(0.58 \pm 0.02 \mu \mathrm{g} \mathrm{mL}^{-1}\right)$. Although this concentration is very low, this drug is highly toxic to mammalian cells, and its action results in a cure rate of approximately 70-80\% in the acute phase, but only $10-20 \%$ for chronic infection..$^{21}$ Even after decades of research there still are no compounds able to cure all Chagas' disease patients; and no substitute for the benznidazole has been developed. ${ }^{21}$

For larvicidal activity against $A$. aegypti larvae, only compound 8 was evaluated due to the high concentration in the hexane extract, showing an $\mathrm{LC}_{50}$ of $62.7 \mu \mathrm{g} \mathrm{mL}^{-1}\left(42.7-86.0 \mu \mathrm{g} \mathrm{mL}^{-1}\right)$, while the $\mathrm{LC}_{50}$ of the positive control (temephos) was $0.042 \mu \mathrm{g} \mathrm{mL}-1$ (0.035$0.050 \mu \mathrm{g} \mathrm{mL}^{-1}$ ). Organophosphates such as temephos have been used as larvicides in several countries since 1960s. However, resistance to pesticides, high cost, toxic hazards to human and other non-target organism has prompted research to find new methods intended to control A. aegypti from natural sources. Additionally, this synthetic insecticide adversely affects the environment by contaminating soil, water and air. When this result is compared with those described by Slimestad et ll $^{22}$ for compound $\mathbf{5}$, who reported a larvicidal activity of $\left(\mathrm{LC}_{100}\right.$ lower than $\left.62.5 \mu \mathrm{g} \mathrm{mL} \mathrm{m}^{-1}\right)$, it highlighted the importance of the hydroxyl group at C-3. These results suggest that these compounds could be used as a model for the development of new larvicidal control against $A$. aegypti, and make an important contribution to the investigation of natural products as potential insecticides and larvicides.

The antifungal and antibacterial activities were also investigated for compounds $\mathbf{5}, \mathbf{8}$ and $\mathbf{9}$. Compound $\mathbf{8}$ was the most active, presenting strong activity against the fungus $C$. glabrata (ATCC 30070) and C. dubliniensis (ATCC 778157) both with MIC values of $62.5 \mu \mathrm{g} \mathrm{mL}^{-1}$ (Table 1). This compound also showed significant antibacterial activity against $S$. aureus (ATCC14458) and $S$. aureus (ATCC6538) both with MIC values of $125 \mu \mathrm{g} \mathrm{mL} \mathrm{m}^{-1}$ (Table 1). Compound $\mathbf{8}$ is a derivative of 5 that differs by having the presence of a hydroxyl group at C-3. This apparent substitution increases its biological activity compared with $\mathbf{5}$ (ent-kaur-16-en-19-oic acid). Although $\mathbf{8}$ was the most active compound, 7 and $\mathbf{9}$ also showed significant results against C. glabrata (ATCC 30070) and C. dubliniensis (ATCC 778157) with MIC values in the $125-250 \mu \mathrm{g} \mathrm{mL}^{-1}$ range (Table 1). Compound 9 was more active against $C$. tropicalis (ATCC 157) with MIC values of $250 \mu \mathrm{g} \mathrm{mL}^{-1}$, compared with $\mathbf{5}$ and $\mathbf{8}$. Although the positive controls chloramphenicol and ketoconazole (Table 1) were more active than the compounds tested, the results obtained were very promising. Further investigations into mechanisms of action are necessary to confirm the potent antifungal and antibacterial activities presented by the ent-kaurane diterpenes. 


\section{EXPERIMENTAL}

\section{General experimental procedures}

IR spectra were acquired in KBr pellets on a Biorad FTS-3500 GX spectrophotometer. Optical rotations were recorded in $\mathrm{MeOH}$ on a Rudolph Research polarimeter. GC-MS analyses were performed on a Shimadzu QP5050A GC-MS system equipped with an AOC20i auto-injector. The chromatograph used was equipped with a J \& W Scientific DB-5MS (coated with 5\%-phenyl-95\%-methylpolysiloxane) fused capillary column $(30 \mathrm{~m} \times 0.25 \mathrm{~mm} \times 0.25 \mu \mathrm{m}$ film thickness). MS were taken at $70 \mathrm{eV}$ with a scan interval of $0.5 \mathrm{~s}$ and fragments from 40-500 Da. Low Resolution Mass Spectra (LRMS) were determined using an ultra-high performance chromatographymass spectrometry system (Acquity UHPLC-TQD - Waters) with an ESI source in the negative ion mode. 1D and 2D NMR data were recorded at $293 \mathrm{~K}$ in $\mathrm{CDCl}_{3}$ or $\mathrm{CDCl}_{3}+$ drops of $\mathrm{CD}_{3} \mathrm{OD}$ on a Bruker Avance III 400 NMR spectrometer, operating at 9.4 Tesla, observing ${ }^{1} \mathrm{H}$ and ${ }^{13} \mathrm{C}$ at 400.13 and $100.61 \mathrm{MHz}$, respectively. The spectrometer was equipped with either, a 5-mm multinuclear direct detection probe (1D NMR experiments) or a 5-mm multinuclear inverse detection probe (1D NOE and 2D NMR experiments) both with $z$-gradient. One-bond and long-range ${ }^{1} \mathrm{H}^{13} \mathrm{C}$ correlation from $\mathrm{HSQC}$ and $\mathrm{HMBC}$ NMR experiments were optimized for an average coupling constant ${ }^{1} J_{(\mathrm{C}, \mathrm{H})}$ and ${ }^{\mathrm{LR}} J_{(\mathrm{C}, \mathrm{H})}$ of 140 and $8 \mathrm{~Hz}$, respectively. All ${ }^{1} \mathrm{H}$ and ${ }^{13} \mathrm{C} \mathrm{NMR}$ chemical shifts $(\delta)$ are given in ppm related to the TMS signal at 0.00 ppm as an internal reference, and the coupling constants $(J)$ in $\mathrm{Hz}$. Silica gel 60 (70-230 mesh) was used for column chromatography, while silica gel $60 \mathrm{~F}_{254}$ was used for analytical $(0.25 \mathrm{~mm})$, and preparative $(1.00 \mathrm{~mm})$ TLC. Compounds were visualized by exposure under $\mathrm{UV}_{254 / 365}$ light and spraying of $p$-anisaldehyde reagent followed by heating on a hot plate.

\section{Plant material}

Stems of $X$. laevigata were collected in "Serra de Itabaiana", in the city of Itabaiana [coordinates: $10^{\circ} 44^{\prime} 53^{\prime \prime} \mathrm{S}, 37^{\circ} 20^{\prime} 21^{\prime \prime} \mathrm{W}$ ], Sergipe State, Brazil, in March 2010. The identity of the plant was confirmed by Dr. A. P. do N. Prata, Department of Biology (DBI), Federal University of Sergipe (UFS), Brazil, and a voucher specimen (\#15440) has been deposited in the Herbarium of the Federal University of Sergipe (ASE/UFS).

\section{Extraction and isolation of chemical constituents}

The dried powdered stem of X. laevigata (1400 g) was successively extracted with hexane followed by $\mathrm{MeOH}$, to yield hexane $(18.77 \mathrm{~g})$ and $\mathrm{MeOH}(87.79 \mathrm{~g})$ extracts. The hexane extract $(5.0 \mathrm{~g})$ was subjected to silica gel column chromatography (CC) eluted with increasing concentrations of $\mathrm{CH}_{2} \mathrm{Cl}_{2}$ in petroleum ether (100:0 to 10:90, $v / v)$, followed by EtOAc in $\mathrm{CH}_{2} \mathrm{Cl}_{2}(100: 0$ to $10: 90, \mathrm{v} / \mathrm{v})$, and $\mathrm{MeOH}$ in EtOAc (100:0 to 70:30, $v / v$ ), affording 133 fractions ( $25 \mathrm{~mL}$ each). The eluted fractions were evaluated and pooled according to TLC analysis, to afford 21 groups (GF1 to GF21). Group GF10 (1450.6 mg) eluted with $\mathrm{CH}_{2} \mathrm{Cl}_{2}$-AcOEt (90:10) was submitted to a new silica gel $\mathrm{CC}$ eluted with the same methodology as above, affording 108 subfractions $(25 \mathrm{~mL}$ each) that were subsequently pooled into 14 groups (GF10.1 to GF10.14), according to TLC analysis. Group GF10.5 (224.7 mg) was submitted to a new silica gel CC eluted with increasing concentrations of $\mathrm{CH}_{2} \mathrm{Cl}_{2}$ in petroleum ether (100:0 to 10:90, v/v), followed by EtOAc in $\mathrm{CH}_{2} \mathrm{Cl}_{2}$ (100:0 to 10:90, v/v), and $\mathrm{MeOH}$ in EtOAc (100:0 to 80:20, v/v), as well as preparative TLC eluted with hexane-EtOAc (90:10, v/v, twice) yielding 5 (77.7 mg).
Group GF10.6 (80.9 mg) was washed with hexane to give again 5 (53.2 mg). Group GF10.7 (319.10 mg) was submitted to the same conditions as for GF10.5 resulting in $\mathbf{5}(92.4 \mathrm{mg})$ and $\mathbf{6}(27.0 \mathrm{mg})$. Group GF10.8 (228.4 mg) was submitted to CC eluted with increasing concentrations of EtOAc in hexane (100:0 to 10:90, v/v), followed by $\mathrm{MeOH}$ in EtOAc (100:0 to 80:20, v/v) giving 41 subfractions $(25 \mathrm{~mL}$ each) that were pooled into 14 groups (GF10.8.1 to GF10.8.14), according to TLC analysis. Group GF10.8.4 (46.0 mg) was submitted to preparative TLC eluted with petroleum ether-EtOAc $(90: 10, \mathrm{v} / \mathrm{v}$, twice) affording $1(8.7 \mathrm{mg})$. Groups GF10.8.7 and GF10.8.8 were pooled $(168.8 \mathrm{mg}$ ) and also submitted to TLC preparative eluted with hexane-EtOAc $(80: 20, \mathrm{v} / \mathrm{v})$, resulting in a mixture of $\mathbf{2 - 4}(66.9 \mathrm{mg})$. Group GF14 (775.5 mg) eluted with $\mathrm{CH}_{2} \mathrm{Cl}_{2}$-AcOEt (50:50) was washed with AcOEt and recrystallized from $\mathrm{CHCl}_{3}-\mathrm{MeOH}(2: 1 \mathrm{v} / \mathrm{v})$, yielding $8(582.5 \mathrm{mg})$. The residue obtained from the wash $(77.1 \mathrm{mg})$ was submitted to preparative TLC eluted with $\mathrm{CH}_{2} \mathrm{Cl}_{2}-\mathrm{MeOH}$ (95:05, $\mathrm{v} / \mathrm{v})$, resulting in 7 (12.5 mg). Group GF15 eluted with $\mathrm{CH}_{2} \mathrm{Cl}_{2}-\mathrm{AcOEt}$ (30:70) was submitted to CC eluted with increasing concentrations of $\mathrm{CH}_{2} \mathrm{Cl}_{2}$ in $\mathrm{MeOH}$ (100:0 to 40:60, v/v) resulting in 37 subfractions (25 mL each) that were pooled into 13 groups (GF15.1 to GF15.13). Group GF15.6 (227.9 mg) was submitted to preparative TLC eluted with $\mathrm{CH}_{2} \mathrm{Cl}_{2}-\mathrm{MeOH}$ (95:05, v/v, twice), again affording 8 (178.8 $\mathrm{mg}$ ). The groups GF18-GF20 (78.2 mg) eluted with AcOEt-MeOH (90:10) were pooled and submitted to preparative TLC eluted with $\mathrm{CH}_{2} \mathrm{Cl}_{2}-\mathrm{MeOH}(90: 10$, v/v), affording 9 (23.3 mg).

\section{Spathulenol (1)}

Colorless oil. The ${ }^{1} \mathrm{H}$ and ${ }^{13} \mathrm{C}$ NMR data were in agreement with those from the literature. ${ }^{11}$ EI-MS $m / z, 220[\mathrm{M}]^{+}$.

\section{Mixture of $\beta$-sitosterol (2), stigmasterol (3) and campesterol (4)}

White needles (Hexane: $\mathrm{CH}_{2} \mathrm{Cl}_{2} 2: 1$ ); mp 135-137 ${ }^{\circ} \mathrm{C}$ (lit. 138$\left.140{ }^{\circ} \mathrm{C}\right),{ }^{23}{ }^{1} \mathrm{H}$ and ${ }^{13} \mathrm{C}$ NMR data were in agreement with those from the literature; ${ }^{12,23} \mathrm{EI}-\mathrm{MS} \mathrm{m} / \mathrm{z} 414,412$, and $400[\mathrm{M}]^{+}$.

ent-kaur-16-en-19-oic acid (5)

White needles; mp $160-162{ }^{\circ} \mathrm{C}$ (lit. $\left.162-166{ }^{\circ} \mathrm{C}\right) ;{ }^{13}[\alpha]_{\mathrm{D}}^{20}-94.2^{\circ}$ (c 0.5, MeOH); IR (KBr) $v_{\max } 3478,2922,2865,1692,1469,1454$, $1260,1053,1033,1013,872 \mathrm{~cm}^{-1} ;{ }^{13} \mathrm{C}$ NMR data were in agreement with those from the literature; ${ }^{13}$ EI-MS $m / z, 302[\mathrm{M}]^{+}$. LRESIMS $[\mathrm{M}-\mathrm{H}]^{-} \mathrm{m} / \mathrm{z}$ 301.4.

\section{4-epi-Kaurenic acid (6)}

Colorless oil; $[\alpha]_{\mathrm{D}}^{20}-90.4^{\circ}$ (c $\left.0.5, \mathrm{MeOH}\right)$; IR (KBr) $v_{\max } 3475$, $2923,2865,1693,1461,1260,1053,1033,1013,870 \mathrm{~cm}^{-1} ;{ }^{1} \mathrm{H}$ and ${ }^{13} \mathrm{C}$ NMR data were in agreement with those from the literature, ${ }^{14}$ EI-MS $m / z, 302\left[\text { [M] }^{+} \text {. LRESIMS [M-H] }\right]^{-} m / z, 301.3$.

ent-163-hydroxy-17-acetoxy-kauran-19-al (7)

White needles (AcOEt: $\mathrm{CH}_{3} \mathrm{OH} 2: 1$ ); mp 80-83 ${ }^{\circ} \mathrm{C} ;[\alpha]_{\mathrm{D}}{ }^{20}-18.7^{\circ}$ (c 0.5, MeOH); IR (KBr) $v_{\max } 3450,2931,2851,1740,1720,1651$, $1462,1260,1101,1037,800 \mathrm{~cm}^{-1} ;{ }^{1} \mathrm{H}$ and ${ }^{13} \mathrm{C}$ NMR data, see Table 2; EI-MS $m / z, 362[\mathrm{M}]^{+}$.

\section{ent-3 $\beta$-hydroxy-kaur-16-en-19-oic acid (8)}

White crystalline powder $\left(\mathrm{CHCl}_{3}: \mathrm{CH}_{3} \mathrm{OH} 2: 1\right)$; mp 218-219 ${ }^{\circ} \mathrm{C}$ (lit. $\left.215-216^{\circ} \mathrm{C}\right) ;^{18}[\alpha]_{\mathrm{D}}{ }^{20}-122.4^{\circ}(\mathrm{c} 0.5, \mathrm{MeOH}) ; \mathrm{IR}(\mathrm{KBr}) \mathrm{v}_{\max } 3436$, 2923, 2852, 1687, 1656, 1446, 1400, 1365, 1249, 1193, 1141, 1091, 1053, 1033, 1011, 999, $871 \mathrm{~cm}^{-1} ;{ }^{1} \mathrm{H}$ and ${ }^{13} \mathrm{C}$ NMR data, see Table 2; EI-MS $m / z, 318\left[^{\mathrm{M}}\right]^{+}$. LRESIMS [M-H] $m / z$ 317.3.

ent-16ß,17-dihydroxy-kauran-19-oic acid (9)

White powder; $\operatorname{mp} 263-265{ }^{\circ} \mathrm{C}$ (lit. $264-266{ }^{\circ} \mathrm{C}$ ); ${ }^{13}[\alpha]_{\mathrm{D}}{ }^{20}-48.3^{\circ}$ 
(c $0.5, \mathrm{MeOH})$; IR (KBr) $v_{\max } 3431,2935,2865,1716,1649,1635$, 1457, 1241, 1053, 1033, 1014, $873 \mathrm{~cm}^{-1} ;{ }^{1} \mathrm{H}$ and ${ }^{13} \mathrm{C}$ NMR data, see Table 2; EI-MS $m / z, 336\left[\mathrm{M}^{+}\right.$. LRESIMS [M-H] ${ }^{-} \mathrm{m} / z$ 335.5.

\section{In vitro trypanocidal assay}

T. cruzi epimastigotes (Y strain) $\left(10^{6} / \mathrm{mL}\right)$ were incubated in the presence of serial dilutions of the extracts and isolated compounds (5-9) from the stem of $X$. laevigata in LIT medium at $28{ }^{\circ} \mathrm{C}$ containing $20 \mathrm{mg} \mathrm{L}^{-1}$ hemin and $10 \%$ fetal calf serum as described by Castellani et al.. ${ }^{24}$ Since the extracts and isolated compounds were diluted in DMSO, an equal volume of this solvent was added to the control. After 4 days of incubation ( $\log$ phase), the number of cells was determined and the $\mathrm{IC}_{50}$ calculated by using the Excel program (Microsoft Office $\left.{ }^{\circledR}\right)$. Benznidazole $\left(\mathrm{IC}_{50}=2.23 \pm 0.08 \mu \mathrm{M}\right)$ was used as a positive control. Three independent assays were performed in duplicate.

\section{Anfungal and antibacterial assay}

X. laevigata stem crude extracts and isolated compounds (Table 1) were evaluated for antifungal and antibacterial activities using the broth microdilution method (96-well microtiter plates), as previously described by Salvador et al..$^{25}$ to give a concentration between 12 and $5000 \mu \mathrm{g} \mathrm{mL}^{-1}$. The minimal inhibitory concentration (MIC) was calculated as the lowest concentration showing complete inhibition of a tested strain. In these tests, chloramphenicol and ketoconazole were used as experimental positive controls, while the solution of DMSOsterile distilled water $(5: 95, \mathrm{v} / \mathrm{v})$ served as the negative control. Each sensitivity test was performed in duplicate for each microorganism evaluated and repeated three times. The strains of microorganisms utilized are shown in Table 1.

\section{Larvicidal assay}

Eggs of A. aegypti larvae from the Rockefeller Colony, were field collected in Aracaju city, Sergipe state, Brazil and laboratory-reared at the Federal University of Sergipe insectary at $27{ }^{\circ} \mathrm{C}$ and $80-85 \%$ relative humidity under a $12: 12 \mathrm{~h}$ light:dark cycle. Adults were provided with a $10 \%$ sucrose solution ad libitum. Assay eggs were obtained attached to paper strips. The paper strips (1000 eggs/L) were placed in a rectangular polyethylene container with natural mineral water. The container was kept in the insectary for hatching and monitoring of larvae development for 3 to 4 days. Larvae were fed with cat food (PurinaTM) to allow regular development. All bioassays were conducted in a walk-in environmental chamber with these environmental conditions. The larvicidal assay was performed according to Costa et al..$^{26}$ Third-instar larvae were used in the experiment. The concentration ranges were determined from a previous concentration-response curve with 20 larvae. A $20,000 \mu \mathrm{g} \mathrm{mL}^{-1}$ (ppm) stock solution was prepared using each extract or isolated compound $\left(20 \mathrm{mg} \mathrm{mL}^{-1}\right)$, Tween-80 (10\% v/v), and natural mineral water $(90 \% \mathrm{v} / \mathrm{v})$. The stock solution was used to make $20 \mathrm{~mL}$ water solutions ranging from 10 to $1000 \mu \mathrm{g} \mathrm{mL}^{-1}$ (ppm). Twenty larvae were collected with a Pasteur pipette, and placed in a $25 \mathrm{~mL}$ graduated cylinder. The volume was made up to $20 \mathrm{~mL}$ with natural mineral water and transferred to disposable cups containing variable volumes of the stock solution. A mortality count was conducted $24 \mathrm{~h}$ after treatment. Controls were prepared with Tween-80 $(0.1 \mathrm{~mL})$, and water $(19.9 \mathrm{~mL})$. Three replicates were used for each concentration and control. For a positive control, the commonly used organophosphorate insecticide, temephos was used at final concentrations ranging from 0.015 to $0.135 \mu \mathrm{g} \mathrm{mL}^{-1}$.
Probit analysis was conducted on mortality data collected after 24 $\mathrm{h}$ exposure to different concentrations of testing solutions to establish the lethal concentration for $50 \%$ mortality $\left(\mathrm{LC}_{50}\right)$ and $95 \%$ confidence intervals (CI) values for the respective compounds and temephos. ${ }^{27} \mathrm{In}$ all cases where deaths had occurred in the control experiment, the data were corrected using Abbott's formula (\% Deaths $=[1-($ test $/$ control $)]$ $x$ 100). Extract or compound activity was considered significantly different when the $95 \%$ CI failed to overlap.

\section{CONCLUSION}

This work reports the isolation and identification of nine compounds described for the first time in X. laevigata. The absolute configurations of the isolated diterpenoids was established, on the basis of values from its specific rotation $\left([\alpha]^{\mathrm{D}}\right)$ as belonging to the ent-kaurane series. The correct stereochemistry of C-16 for compounds $\mathbf{7}$ and $\mathbf{9}$, and $\mathrm{C}-3$ for compound $\mathbf{8}$ was defined according to NMR experiments and literature data. Compound $\mathbf{8}$ is described for the first time in the Annonaceae family, while compound $\mathbf{5}$ is very common in the Annonaceae, particulary in the genera Annona and Xylopia. The presence of ent-kaurane diterpenes in X. laevigata contributed to the chemotaxonomy of Xylopia, supporting these compounds as chemotaxonomic markers. Although compound $\mathbf{5}$ has activity against trypomastigote forms of $T$. cruzi, no activity was observed against epimastigote forms. Further investigation of activity against amastigote forms is necessary to conclude the action of this compound in T. cruzi. Compound $\mathbf{8}$ showed significant activity against $A$. aegypti larvae, suggesting that this compound could be used as a model for development of new larvicidal control against $A$. aegypti. Moreover, compound $\mathbf{8}$ also showed antifungal and antibacterial activities predominantly against Candida spp. and $S$. aureus.

\section{SUPPLEMENTARY MATERIAL}

The ${ }^{1} \mathrm{H},{ }^{13} \mathrm{C}\left\{{ }^{1} \mathrm{H}\right\}$, DEPT 135, 1D NOE, COSY, HSQC, and HMBC NMR experiments for ent-kaurane diterpenoids 7-9 are available free of charge at http://quimicanova.sbq.org.br as a PDF file.

\section{ACKNOWLEDGEMENTS}

The authors are grateful to FAPITEC/SE (Editais No 07/2009 and 10/2009), CNPq, CAPES and FAPESP for financial support, and Prof. Dr. A. P. do N. Prata of the DBI/UFS for the botanical identification.

\section{REFERENCES}

1. Maas, P. J. M.; Maas, H.; Miralha, J. M. S.; Junikka, L.; Rodriguésia 2007, 58, 617 .

2. Corrêa, M. P.; Dicionário das plantas úteis do Brasil e das exóticas cultivadas, IBDF: Rio de Janeiro, 1984; Karioti, A.; Hadjipavlou-Litina, D.; Mensah, M. L. K.; Fleischer, T. C.; Skaltsa, H.; J. Agric. Food Chem. 2004, 52, 8094 .

3. Maia, J. G. S.; Andrade, E. H. A.; Da Silva, A. C. M.; Oliveira, J.; Carreira, L. M. M.; Araújo, J. S.; Flavour Fragance J. 2005, 20, 474; Moreira, I. C.; Lago, J. H. G.; Young, M. C. M.; Roque, N. F.; J. Braz. Chem. Soc. 2003, 14, 828.

4. Da Silva, M. S.; Tavares, J. F.; Queiroga, K. F.; Agra, M. F.; BarbosaFilho, J. M.; Almeida, J. R. G. S.; Da Silva, S. A. S.; Quim. Nova 2009, 32, 1566; Puvanendran, S.; Wickramasinghe, A.; Karunaratne, D. N.; Carr, G.; Wijesundara, D. S. A.; Andersen, R.; Karunaratne, V.; Pharm. Biol. 2008, 46, 352 .

5. López, R.; Cuca, L. E.; Delgado G.; Parasite Immunol. 2009, 31, 623. 
6. Castelo-Branco, M. V. S.; Tavares, J. F.; Silva, M. S.; Barbosa Filho, J. M.; Anazetti, M. C.; Frungillo, L.; Haun, M.; Diniz, M. F. F. M.; Melo, P. S.; Rev. Bras. Farmacogn. 2011, 21, 1035.

7. Nishiyama, Y.; Moriyasu, M.; Ichimaru, M.; Iwasa, K.; Kato, A.; Mathenge, S. G.; Mutiso, P. B. C.; Juma, F. D.; J. Nat. Med. 2010, 64, 9.

8. Pontes, W. J. T.; Oliveira, J. C. S.; Câmara, C. A. G.; Gondim Jr., M. G. C.; Oliveira, J. V.; Schwartz, M. O. E.; Quim. Nova 2007, 30, 838.

9. Nguemtchouin, M. M. G.; Ngassoum, M. B.; Ngamo, L. S. T.; Gaudu, X.; Cretin, C.; Crop Protect. 2010, 29, 985.

10. Pontes, A. F.; Barbosa, M. R. V.; Maas, P. J. M.; Acta Bot. Bras. 2004, 18, 281; Maas, P. J. M.; Kamer, H. M.; Junikka, L.; Mello-Silva, R.; Rainer, H.; Rodriguésia 2001, 52, 61; Maas, P. J. M.; Westra, L. Y. T.; Rainer, H.; Lobão, A. Q.; Erkens, R. H. J. ; Nord. J. Bot. 2011, $29,257$.

11. Ragasa, C. Y.; Ganzon, J.; Hofileña, J.; Tamboong, B.; Rideout, J. A.; Chem. Pharm. Bull. 2003, 51, 1208.

12. Facundo, V. A.; Polli, A. R.; Rodrigues, R. V.; Militão, J. S. L. T.; Stabelli, R. G.; Cardoso, C. T.; Acta Amaz. 2008, 38, 733.

13. Wu, Y.-C.; Hung, Y.-C.; Chang, F.-R.; Cosentino, M.; Wang, H.-K.; Lee, K.-H.; J. Nat. Prod. 1996, 59, 635; Vieira, H. S.; Takahashi, J. A.; De Oliveira, A. B.; Chiari, E.; Boaventura, M. A. D.; J. Braz. Chem. Soc. 2002, 13, 151.

14. Li, C.; Lee, D.; Graf, T. N.; Phifer, S. S.; Nakanishi, Y.; Riswan, S.; Setyowati, F. M.; Saribi, A. M.; Soejarto, D. D.; Farnsworth, N. R.; Falkinham III, J. O.; Kroll, D. J.; Kinghorn, A. D.; Wani, M. C.; Oberlies, N. H.; J. Nat. Prod. 2009, 72, 1949.

15. Leboeuf, M.; Cavé, A.; Bhaumik, P. K.; Mukherjee, B.; Mukherjee, R.; Phytochemistry 1982, 21, 2783; Takahashi, J. A.; Boaventura, M. A. D.; Bayma, J. C.; Oliveira, A. B.; Phytochemistry 1995, 40, 607; Takahashi, J. A.; Vieira, H. S.; Boaventura, M. A. D.; Hanson, J. R.; Hitchcock, P.
B.; Oliveira, A. B.; Quim. Nova 2001, 24, 616; Chen, C.-Y.; Chang, F.R.; Wu, Y.-C.; J. Chin. Chem. Soc. 1997, 44, 313.

16. Lunnon, M. W.; MacMillan, J.; Phinney, B. O.; J. Chem. Soc. Perkin Trans. 1 1977, 20, 2308.

17. Barrero, A. F.; Oltra, J. E.; Cabrera, E.; Reyes, F.; Álvarez, M.; Phytochemistry 1999, 50, 1133.

18. Rezende, M. C.; Urzua, A.; Bortoluzzi, A. J.; Vásquez, L.; J. Ethnopharmacol. 2000, 72, 459.

19. Velandia, J. R.; Carvalho, M. G.; Braz-Filho, R.; Quim. Nova 1998, 21, 397.

20. Alves, T. M. A.; Chaves, P. P. G.; Santos, L. M. S. T.; Nagem, T. J.; Murta, S. M. F.; Geravolo, I. P.; Romanha, A. J.; Zani, C. L.; Planta Med. 1995, 61, 85.

21. Izumi, E.; Ueda-Nakamura, T.; Dias Filho, B. P.; Veiga Júnior, V. F.; Nakamura, C. V.; Nat. Prod. Rep. 2011, 28, 809.

22. Slimestad, R.; Marston, A.; Mavi, S.; Hostettmann, K.; Plant Med. 1995, $61,562$.

23. Costa, E. V.; Marques, F. A.; Pinheiro, M. L. B.; Braga, R. M.; Delarmelina, C.; Duarte, M. C. T.; Ruiz, A. L. T. G.; Carvalho, J. E.; Maia, B. H. L. N. S.; J. Braz. Chem. Soc. 2011, 22, 1111.

24. Castellani, O.; Ribeiro, L. V.; Fernandes, J. F.; J. Protozool. 1967, 14, 447.

25. Salvador, M. J.; Ferreira, E. O.; Pral, E. M. F.; Alfieri, S. C.; Albuquerque, S.; Ito, I. Y.; Dias, D. A.; Phytomedicine 2002, 9, 566.

26. Costa, E. V.; Dutra, L. M.; De Jesus, H. C. R.; Nogueira, P. C. L.; Moraes, V. R. S.; Salvador, M. J.; Cavalcanti, S. C. H.; Dos Santos, R. L. C.; Prata, A. P. N.; Nat. Prod. Commun. 2011, 6, 907.

27. Finney, D. J.; Stevens W. L.; Biometrika 1948, 35, 191. 


\section{ent-KAURANE DITERPENOIDS AND OTHER CONSTITUENTS FROM THE STEM OF Xylopia laevigata} (ANNONACEAE)

Dayanne Meneses Silva, Emmanoel Vilaça Costa*, Paulo Cesar de Lima Nogueira e Valéria Regina de Souza Moraes Departamento de Química, Universidade Federal de Sergipe, Av. Mal. Rondon, s/n, 49100-000 São Cristóvão - SE, Brasil Sócrates Cabral de Holanda Cavalcanti

Departamento de Farmácia, Universidade Federal de Sergipe, Av. Mal. Rondon, s/n, 49100-000 São Cristóvão - SE, Brasil Marcos José Salvador

Curso de Farmácia, Departamento de Biologia Vegetal, Instituto de Biologia, Universidade Estadual de Campinas, CP 6109, 13083-970 Campinas - SP, Brasil

Luis Henrique Gonzaga Ribeiro e Fernanda Ramos Gadelha

Departamento de Bioquímica, Instituto de Biologia, Universidade Estadual de Campinas, CP 6109, 13083-970 Campinas - SP, Brasil Andersson Barison

Departamento de Química, Universidade Federal do Paraná, CP 19081, 81531-990 Curitiba - PR, Brasil

Antonio Gilberto Ferreira

Departamento de Química, Universidade Federal de São Carlos, CP 676, 13565-905 São Carlos - SP, Brasil

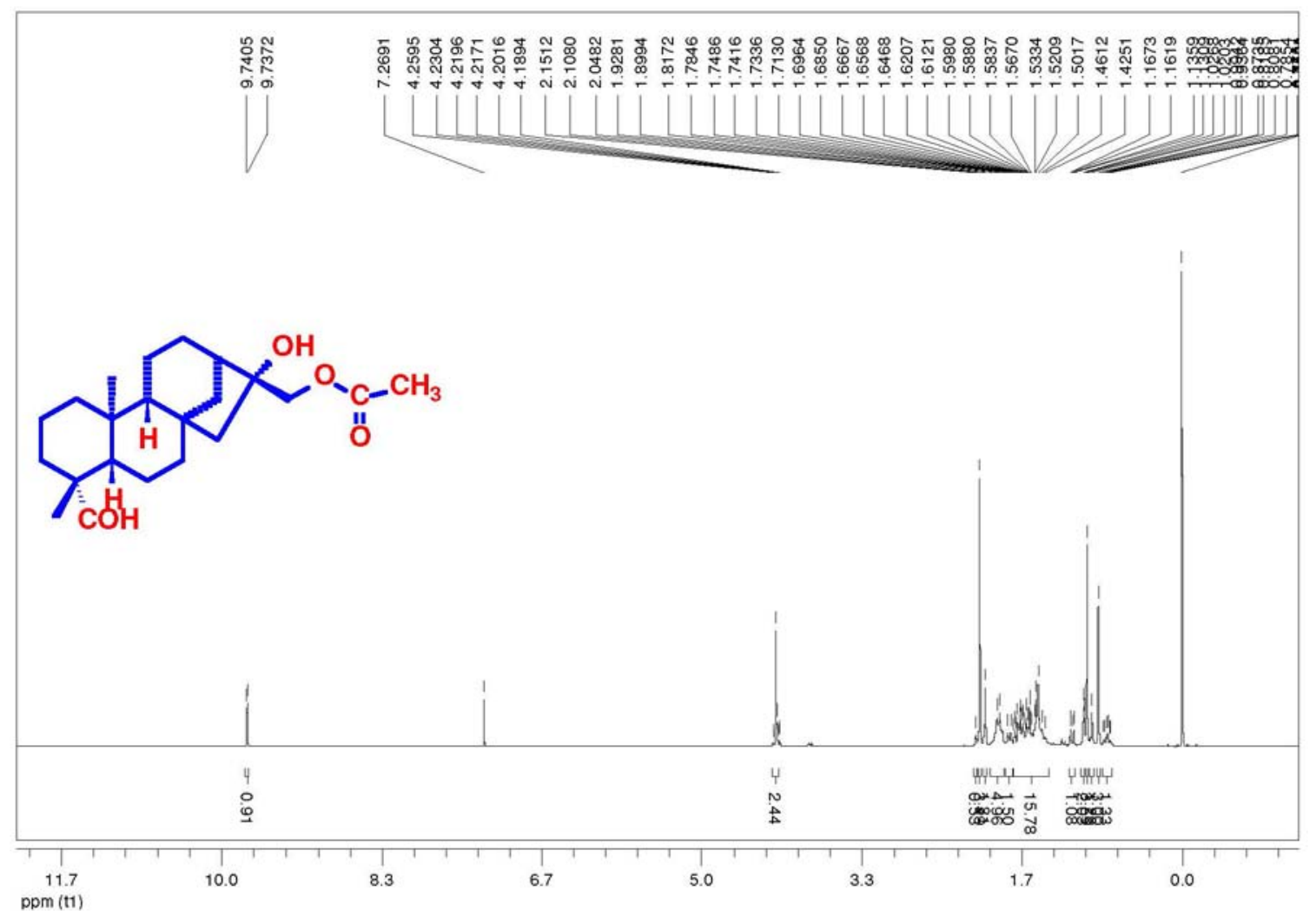

Figure 1S. ${ }^{1} \mathrm{H}$ NMR spectrum of ent-163-hydroxy-17-acetoxy-kauran-19-al (7) in $\mathrm{CDCl}_{3}$ at $400 \mathrm{MHz}$ 


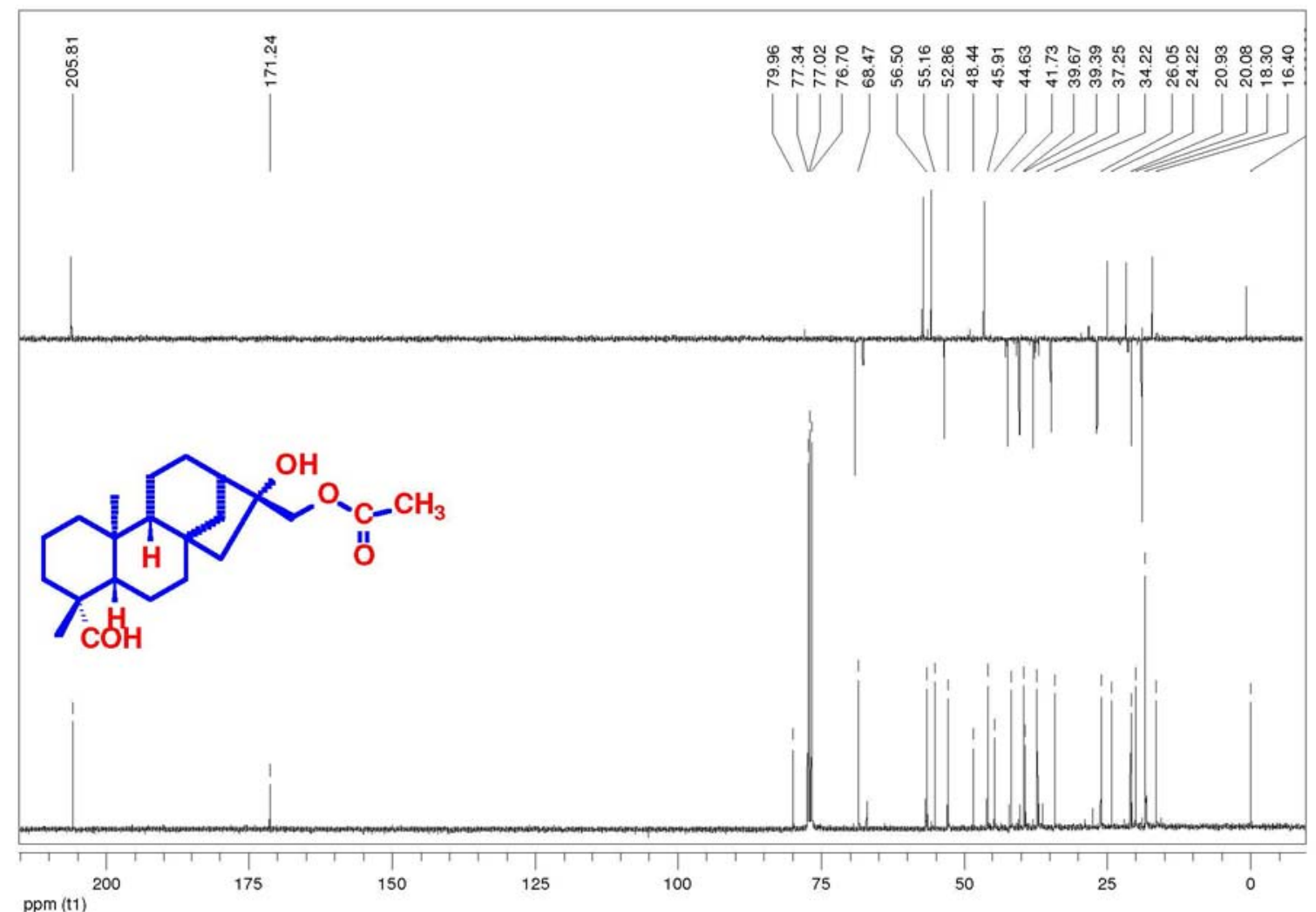

Figure 2S. ${ }^{13} \mathrm{C}\left\{{ }^{1} \mathrm{H}\right\}$ and DEPT $135 \mathrm{NMR}$ spectra of ent-16 $\beta$-hydroxy-17-acetoxy-kauran-19-al (7) in CDCl at $100 \mathrm{MHz}$

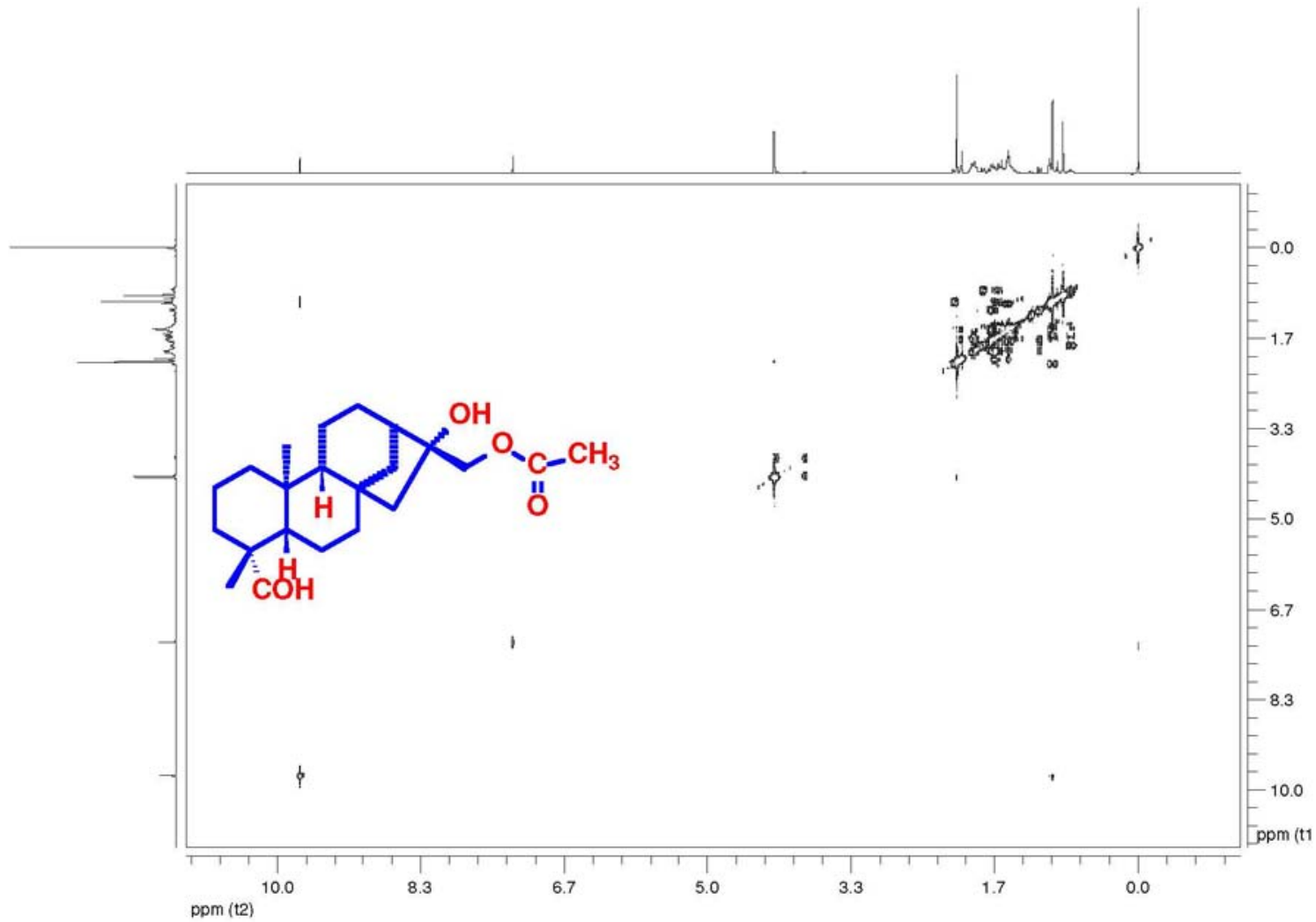

Figure 3S. ${ }^{1} \mathrm{H}-{ }^{-1} \mathrm{H}$ correlation map from COSY NMR experiment of ent-163-hydroxy-17-acetoxy-kauran-19-al (7) in CDCl at $400 \mathrm{MHz}$ 


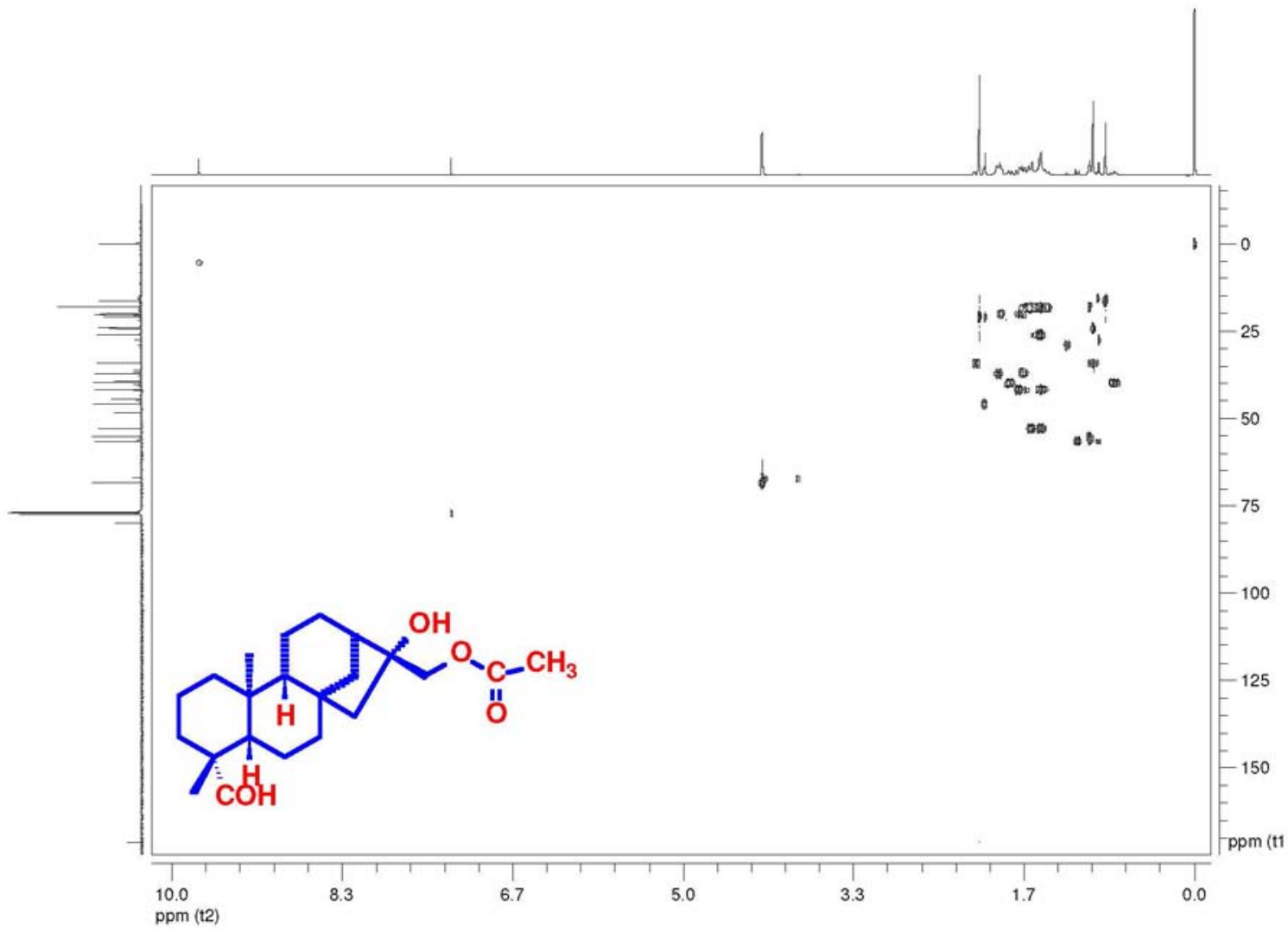

Figure 4S. ${ }^{1} \mathrm{H}_{-13}{ }^{13} \mathrm{C}$ one-bond correlation map from HSQC NMR experiment of ent-16 $\beta$-hydroxy-17-acetoxy-kauran-19-al (7) in CDCl ${ }_{3}$ at 400 and $100 \mathrm{MHz}$

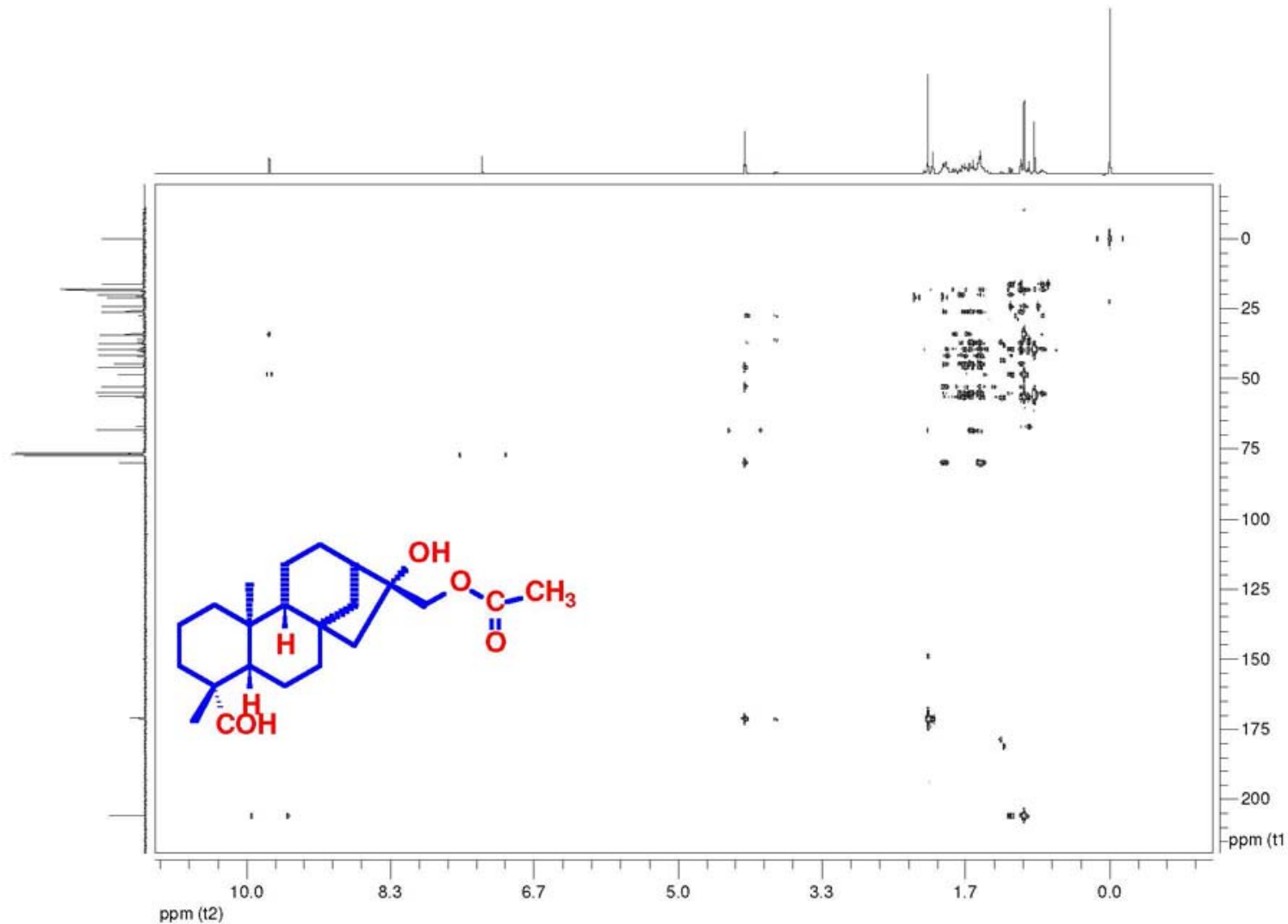

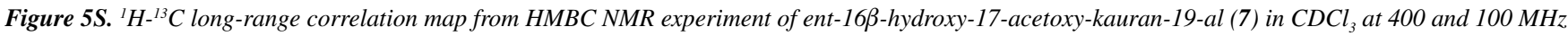



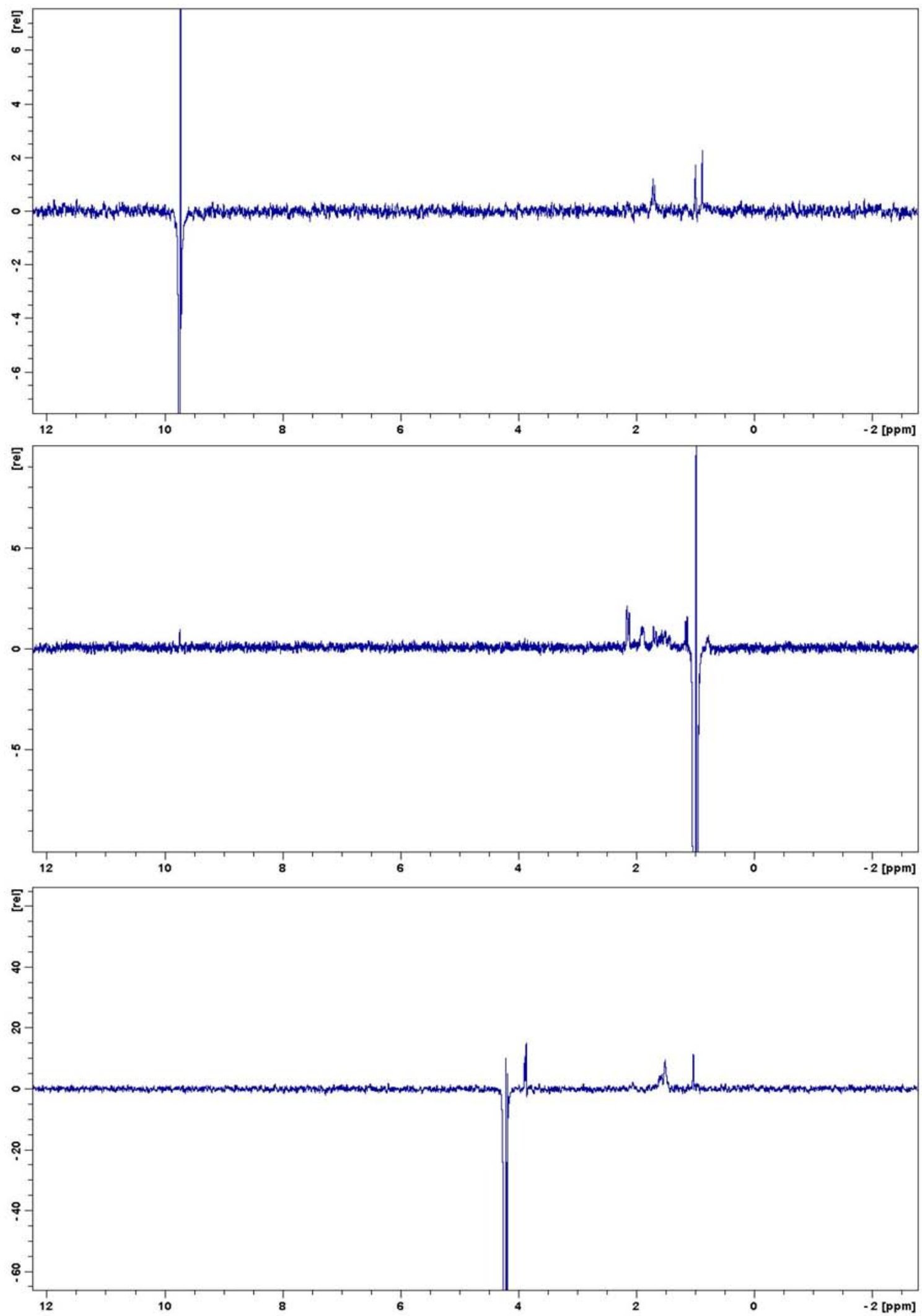

Figure 6S. $1 D$ NOE experiments for ent-16 $\beta$-hydroxy-17-acetoxy-kauran-19-al (7) in $\mathrm{CDCl}_{3}$ at $400 \mathrm{MHz}$ 


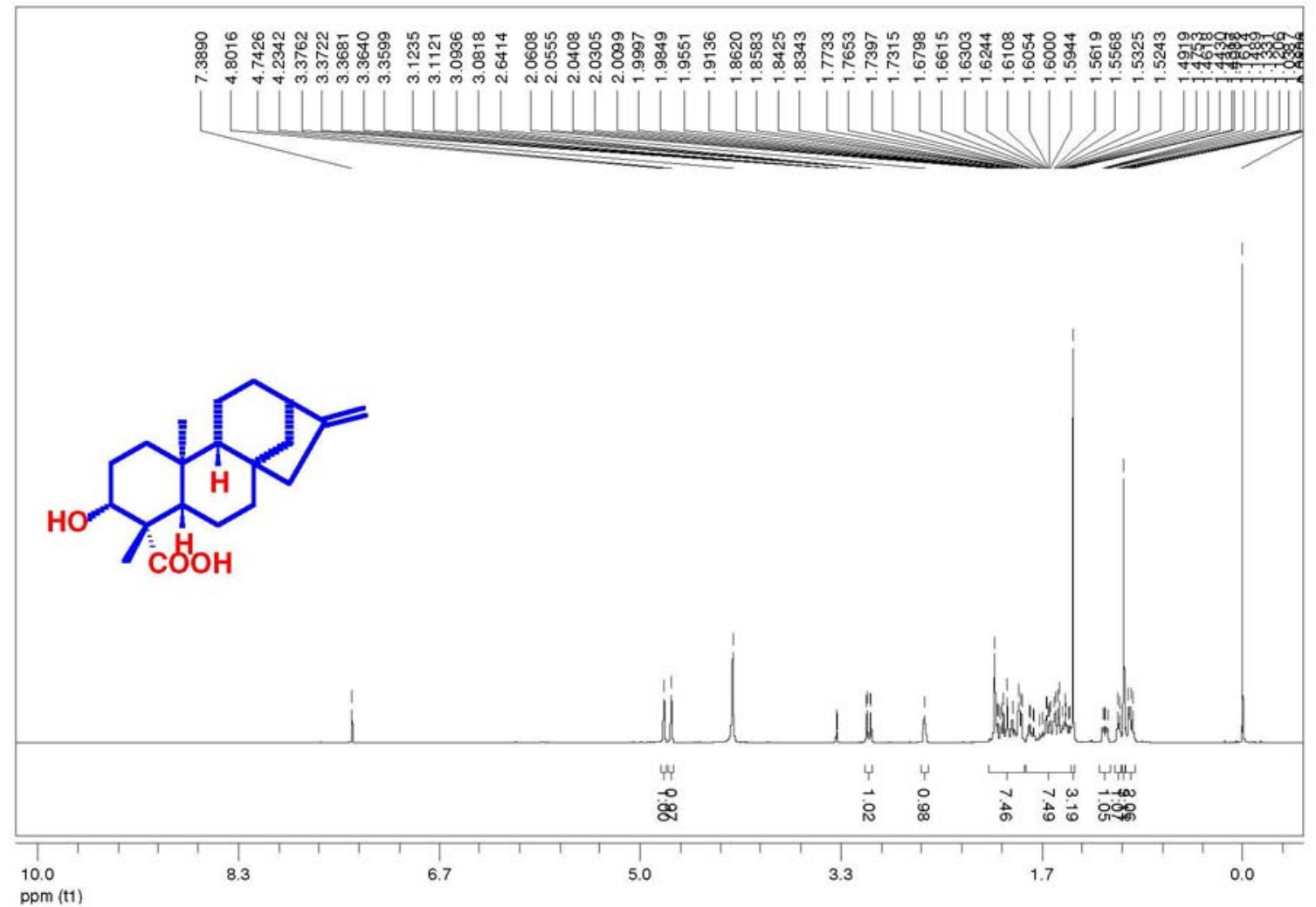

Figure 7S. ${ }^{1} \mathrm{H} N M R$ spectrum of ent-3 $\beta$-hydroxy-kaur-16-en-19-oic acid (8) in $\mathrm{CDCl}_{3}+$ drops of $\mathrm{CD}_{3} \mathrm{OD}$ at $400 \mathrm{MHz}$

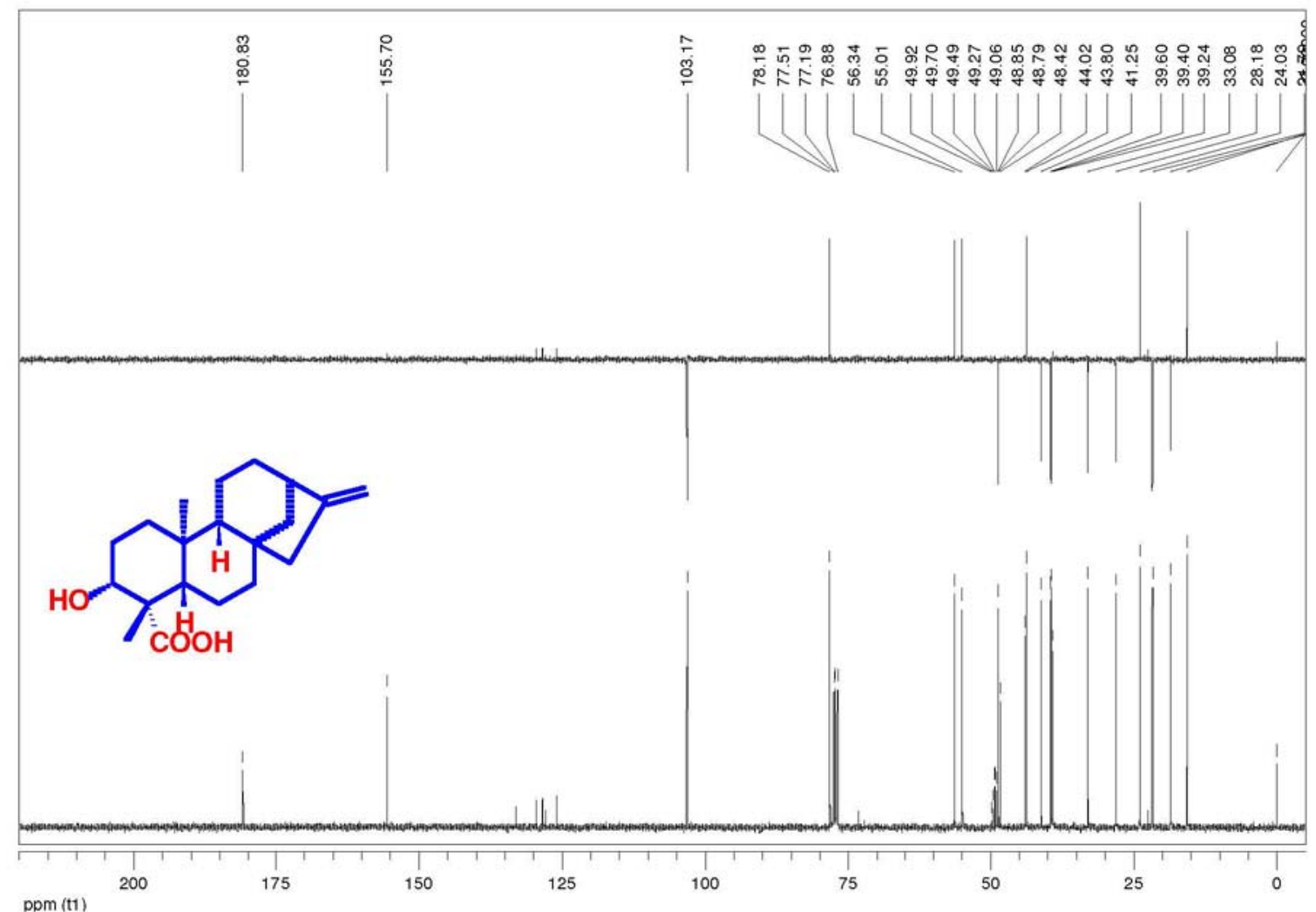

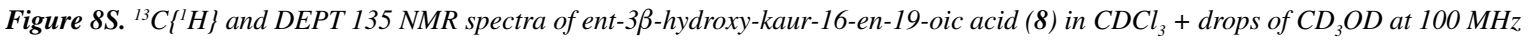




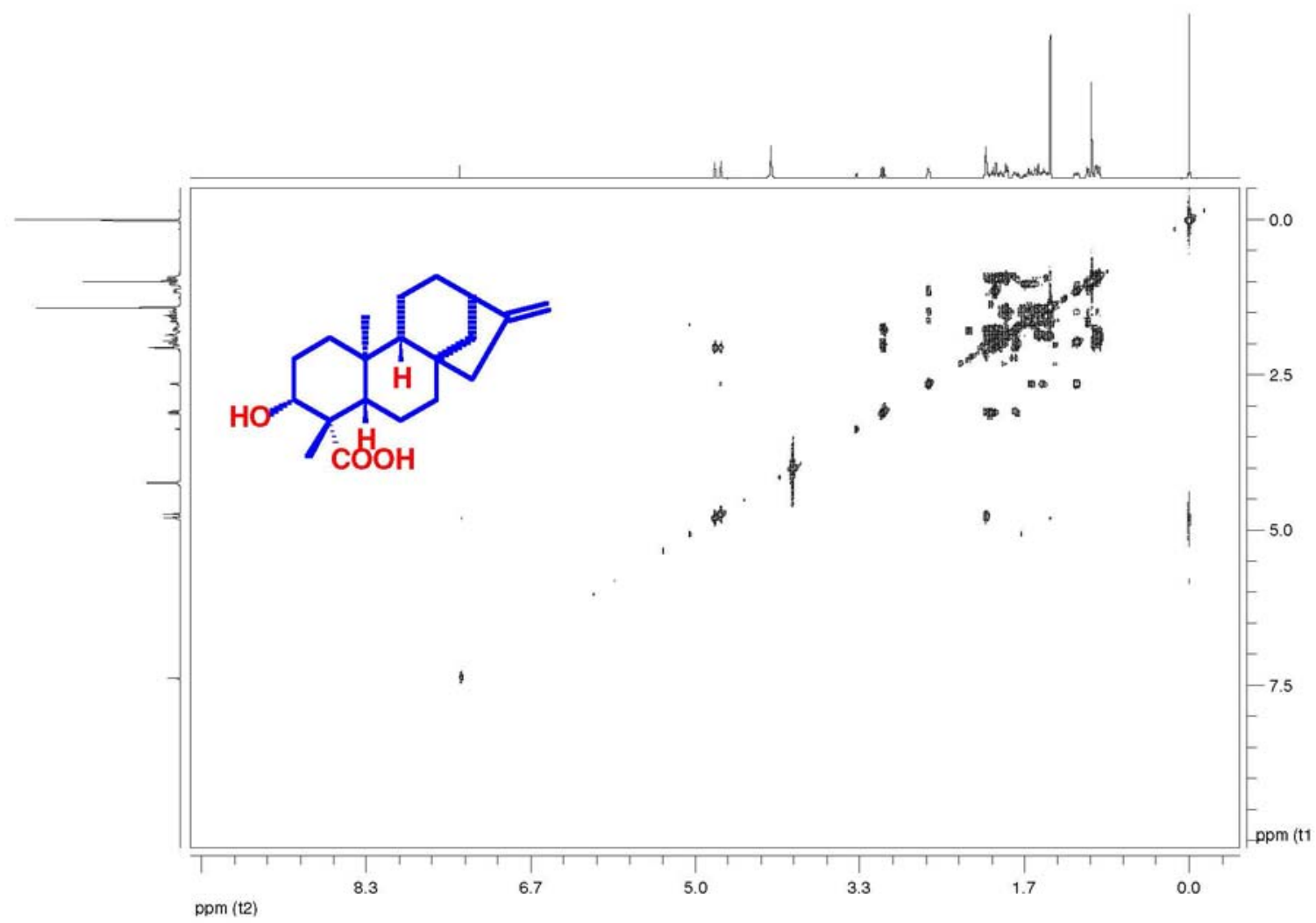

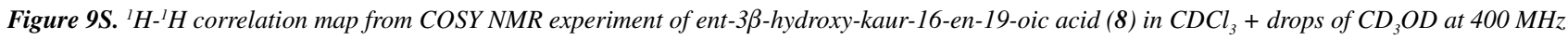

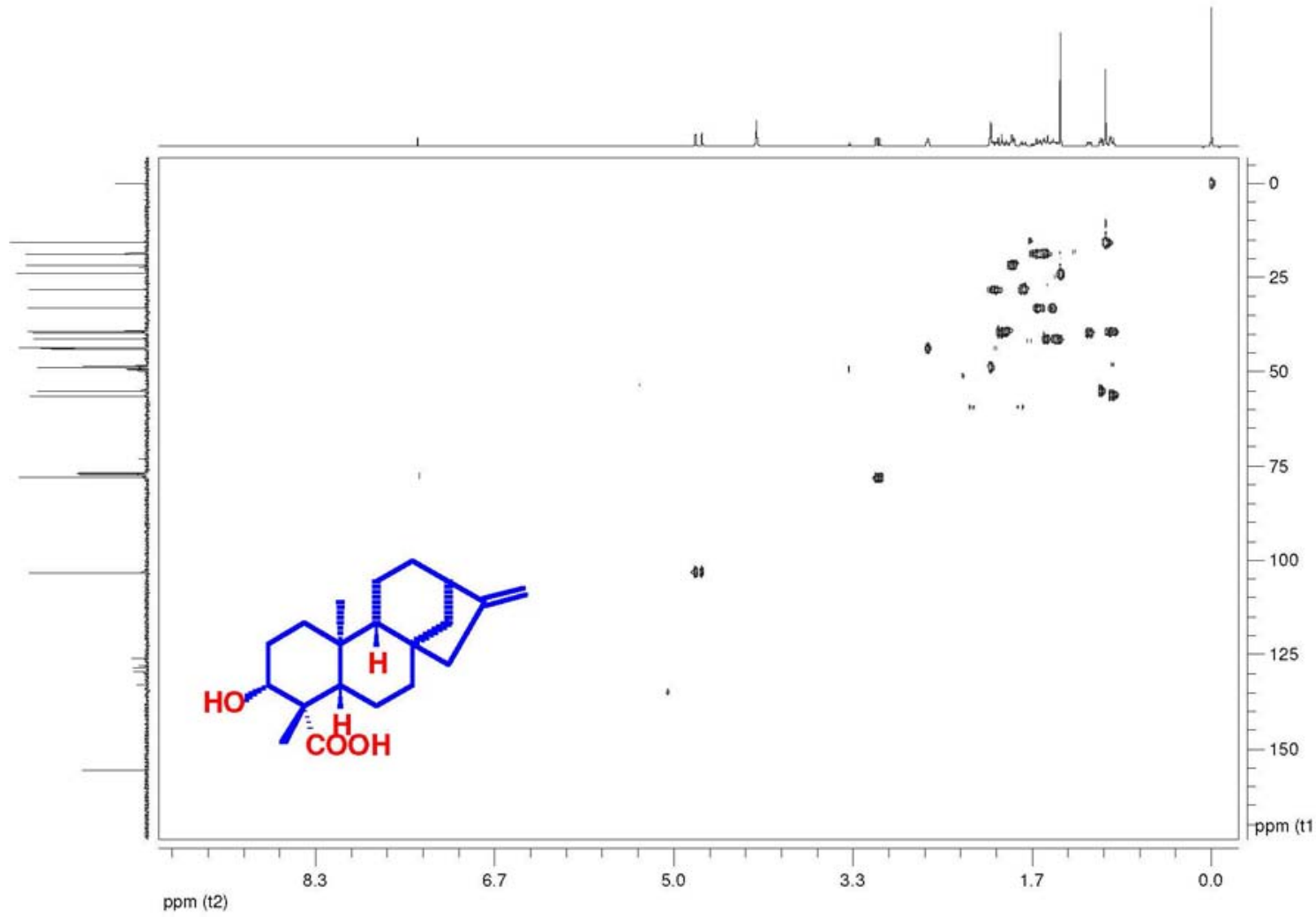

Figure 10S. ${ }^{1} \mathrm{H}_{-}{ }^{13} \mathrm{C}$ one-bond correlation map from $\mathrm{HSQC} \mathrm{NMR} \mathrm{experiment} \mathrm{of} \mathrm{ent-3 \beta -hydroxy-kaur-16-en-19-oic} \mathrm{acid}(8)$ in $\mathrm{CDCl}_{3}+$ drops of $\mathrm{CD}_{3} \mathrm{OD}$ at 400 and $100 \mathrm{MHz}$ 


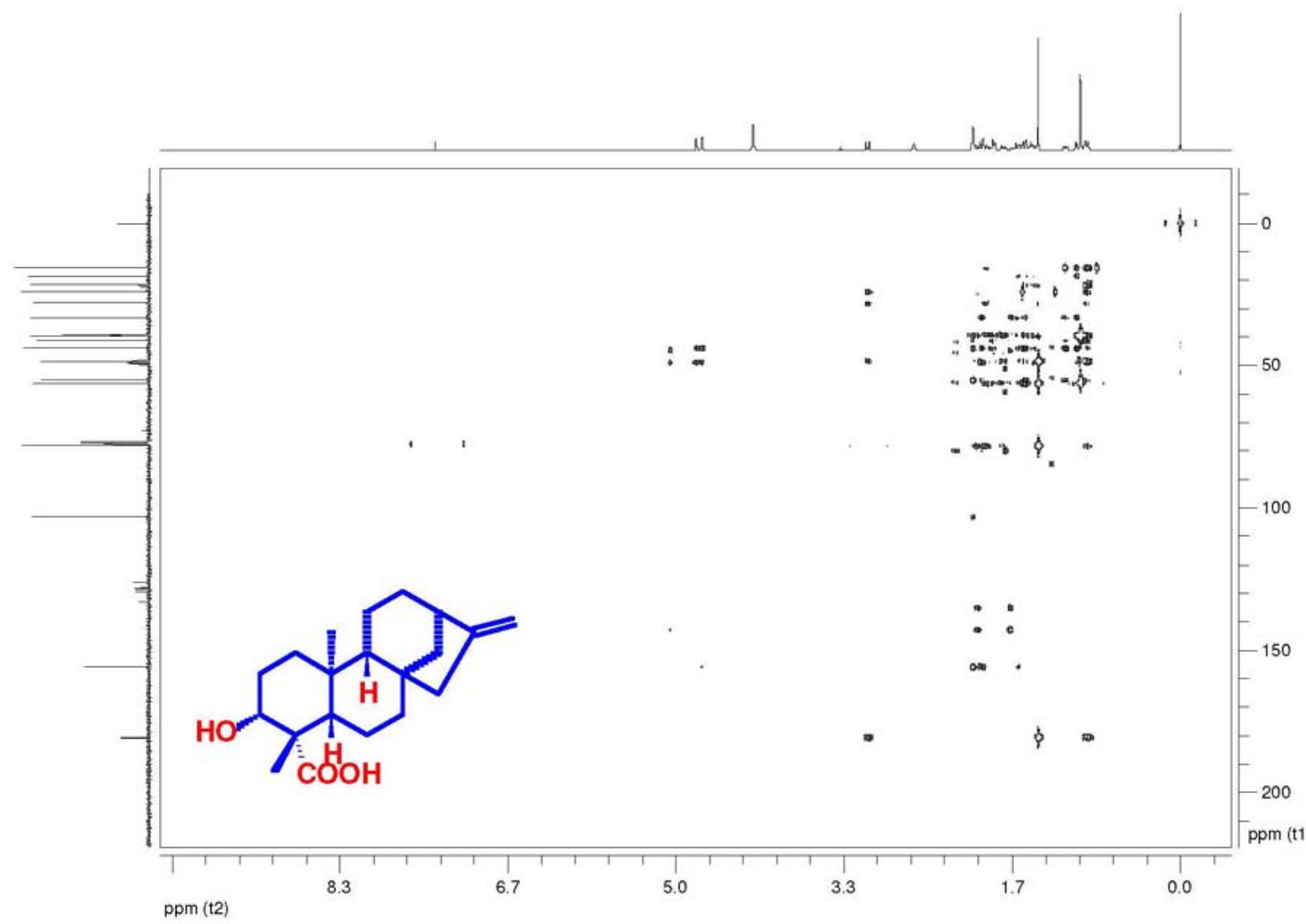

Figure 11S. ${ }^{1} \mathrm{H}-{ }^{13} \mathrm{C}$ long-range correlation map from $\mathrm{HMBC}$ NMR experiment of ent-3 $\beta$-hydroxy-kaur-16-en-19-oic acid $(8)$ in $\mathrm{CDCl}_{3}+$ drops of $\mathrm{CD}_{3} \mathrm{OD}$ at 400 and $100 \mathrm{MHz}$ 

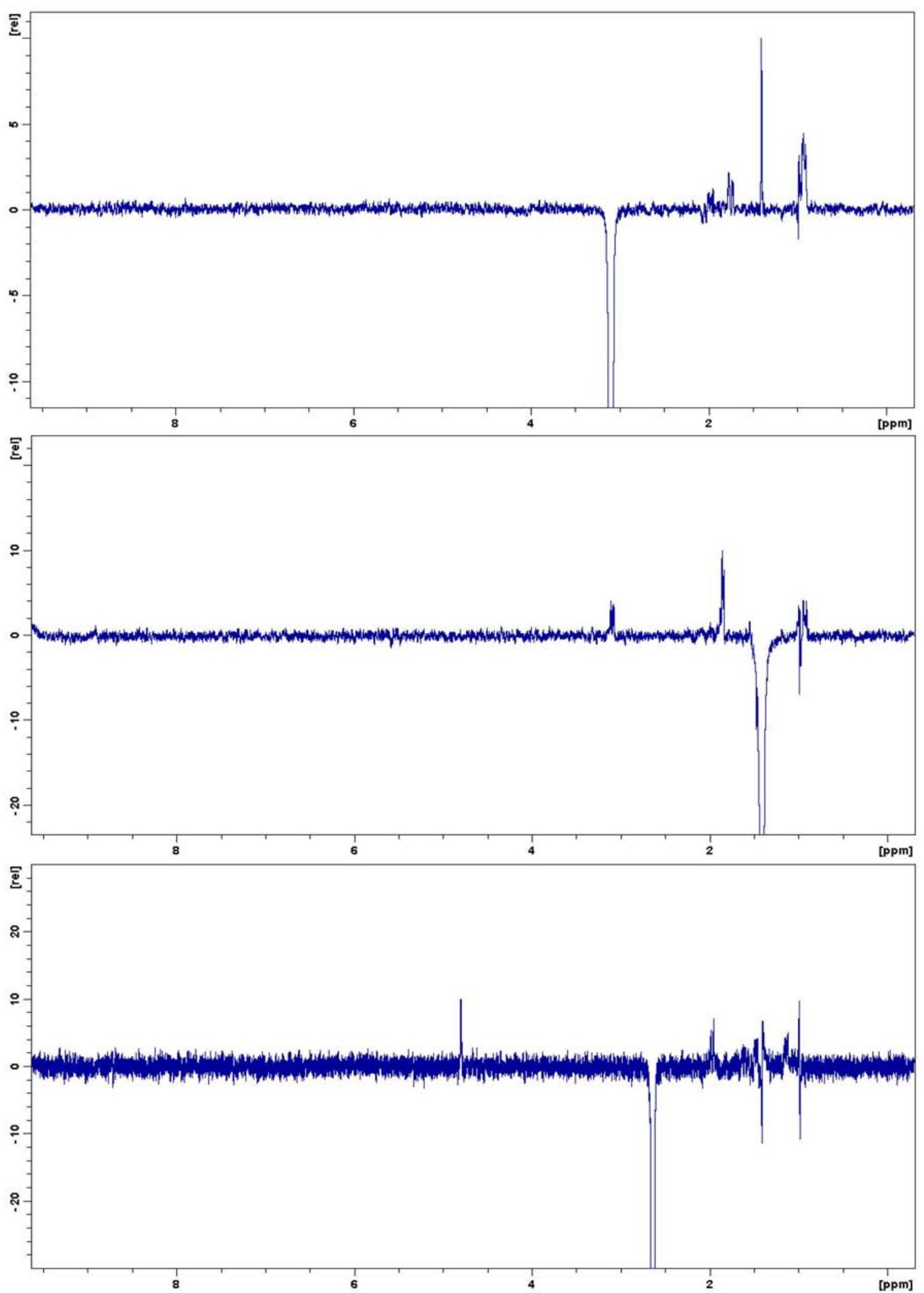

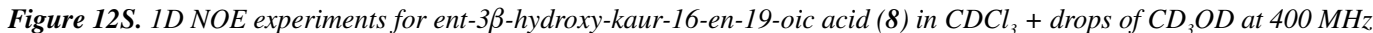




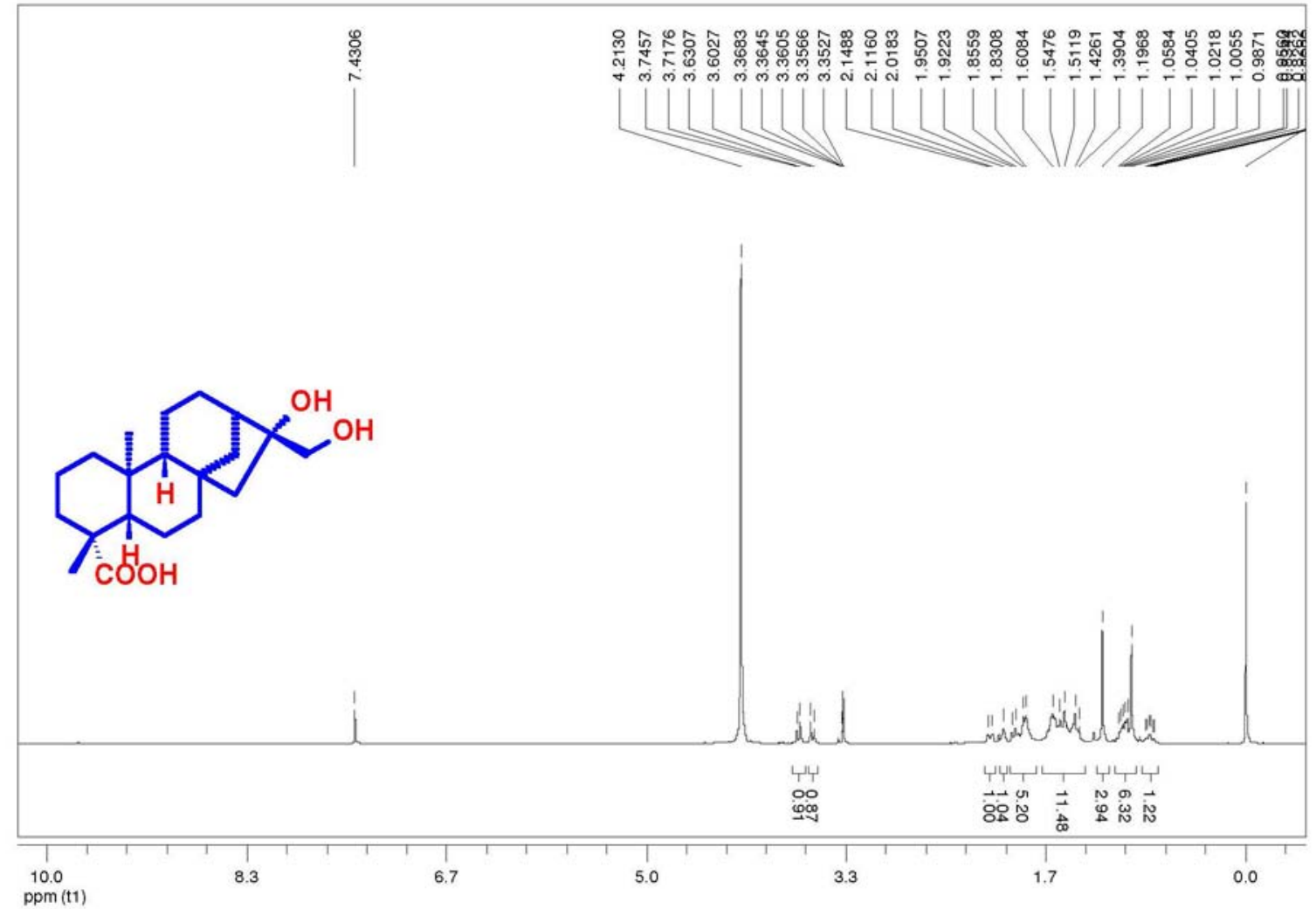

Figure 13S. ${ }^{1} \mathrm{H}$ NMR spectrum of ent-16ק,17-dihydroxy-kauran-19-oic acid (9) in $\mathrm{CDCl}_{3}+$ drops of $\mathrm{CD}_{3} \mathrm{OD}$ at $400 \mathrm{MHz}$

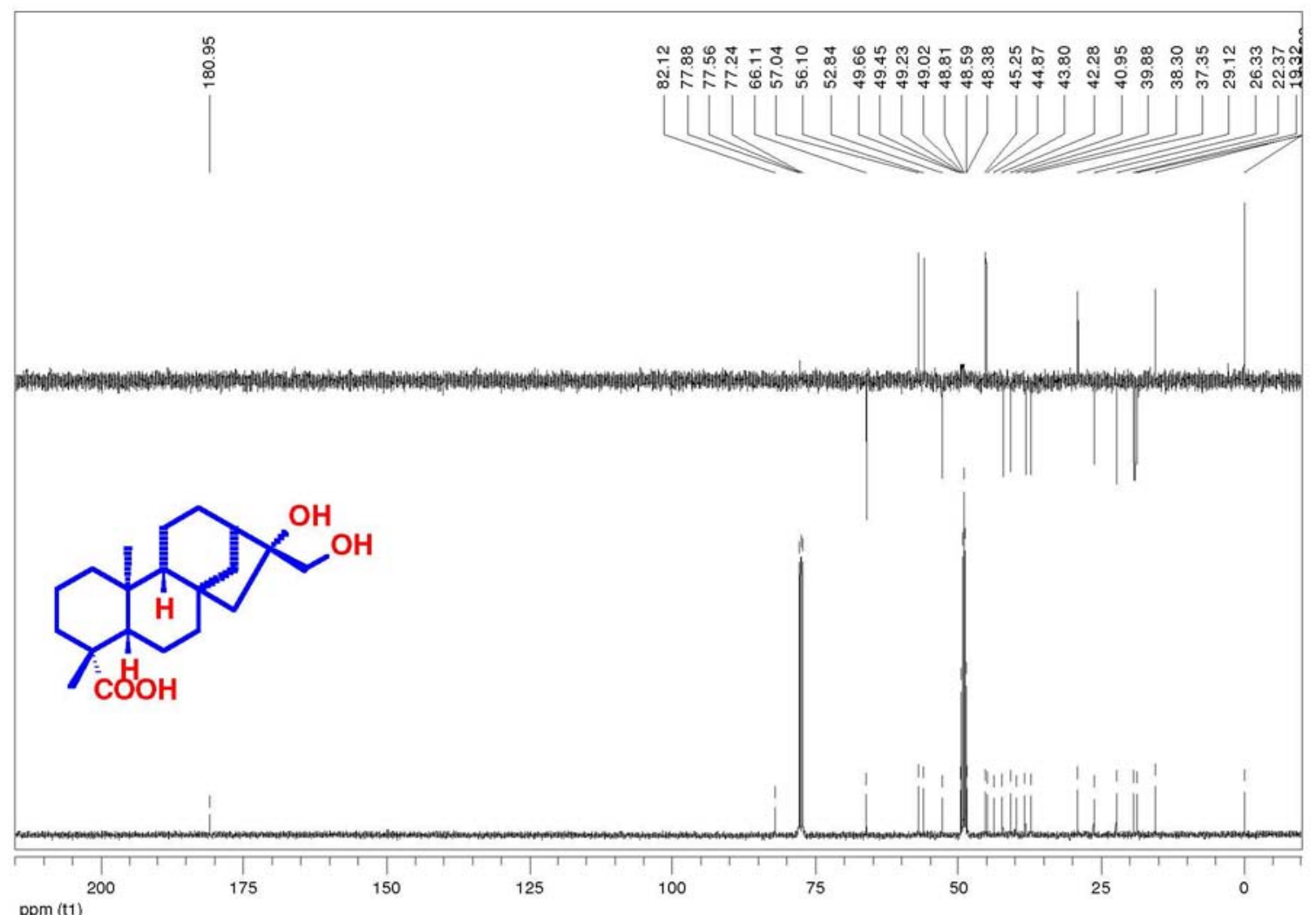

Figure 14S. $\left.{ }^{13} \mathrm{C}^{1} \mathrm{H}\right\}$ and DEPT $135 \mathrm{NMR}$ spectra of ent-16 $\beta$,17-dihydroxy-kauran-19-oic acid (9) in $\mathrm{CDCl}_{3}+$ drops of $\mathrm{CD}_{3} \mathrm{OD} \mathrm{at} 100 \mathrm{MHz}$ 


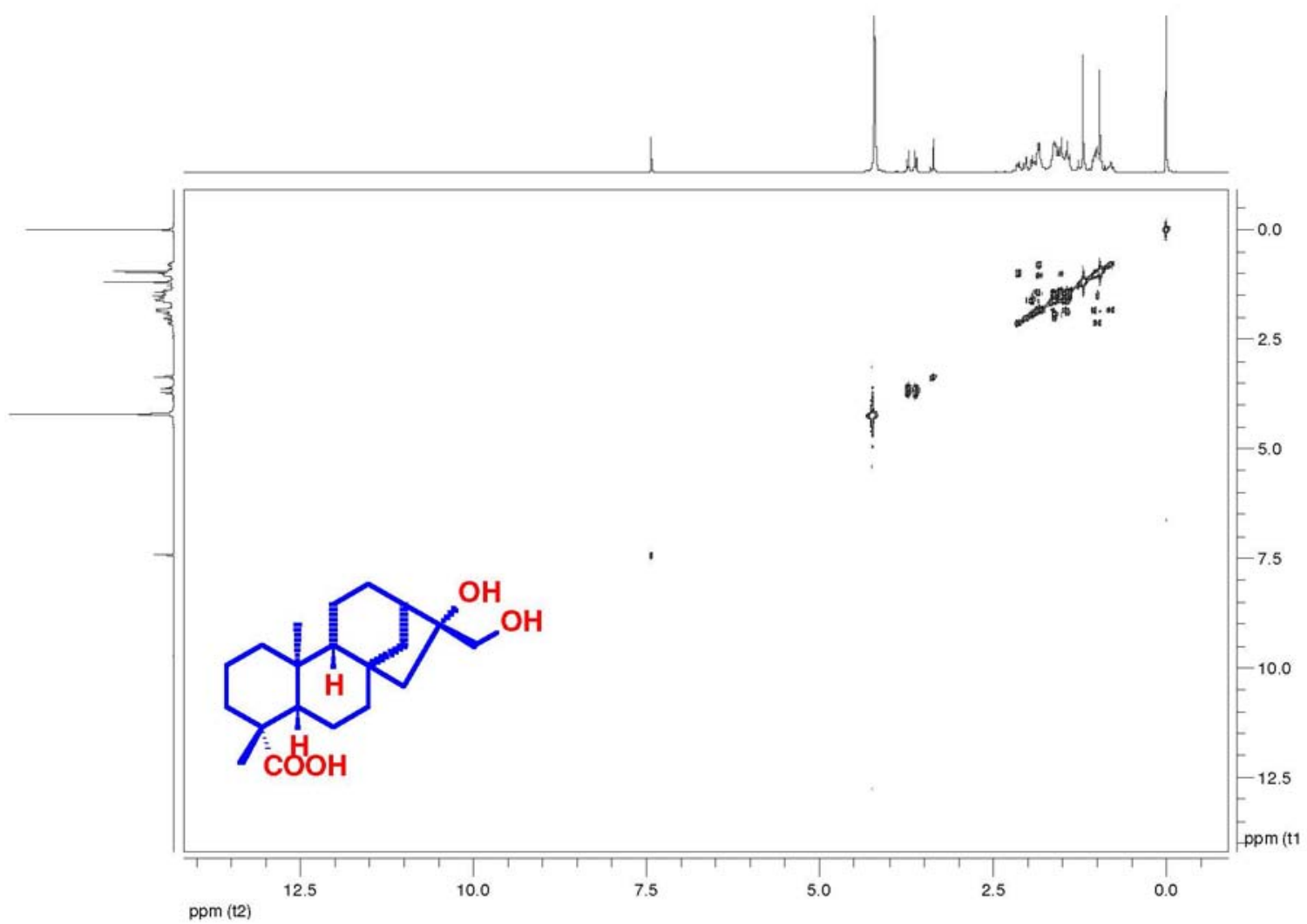

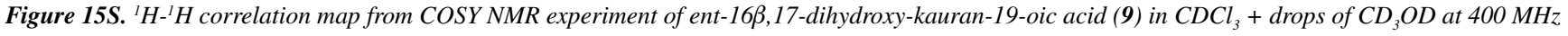

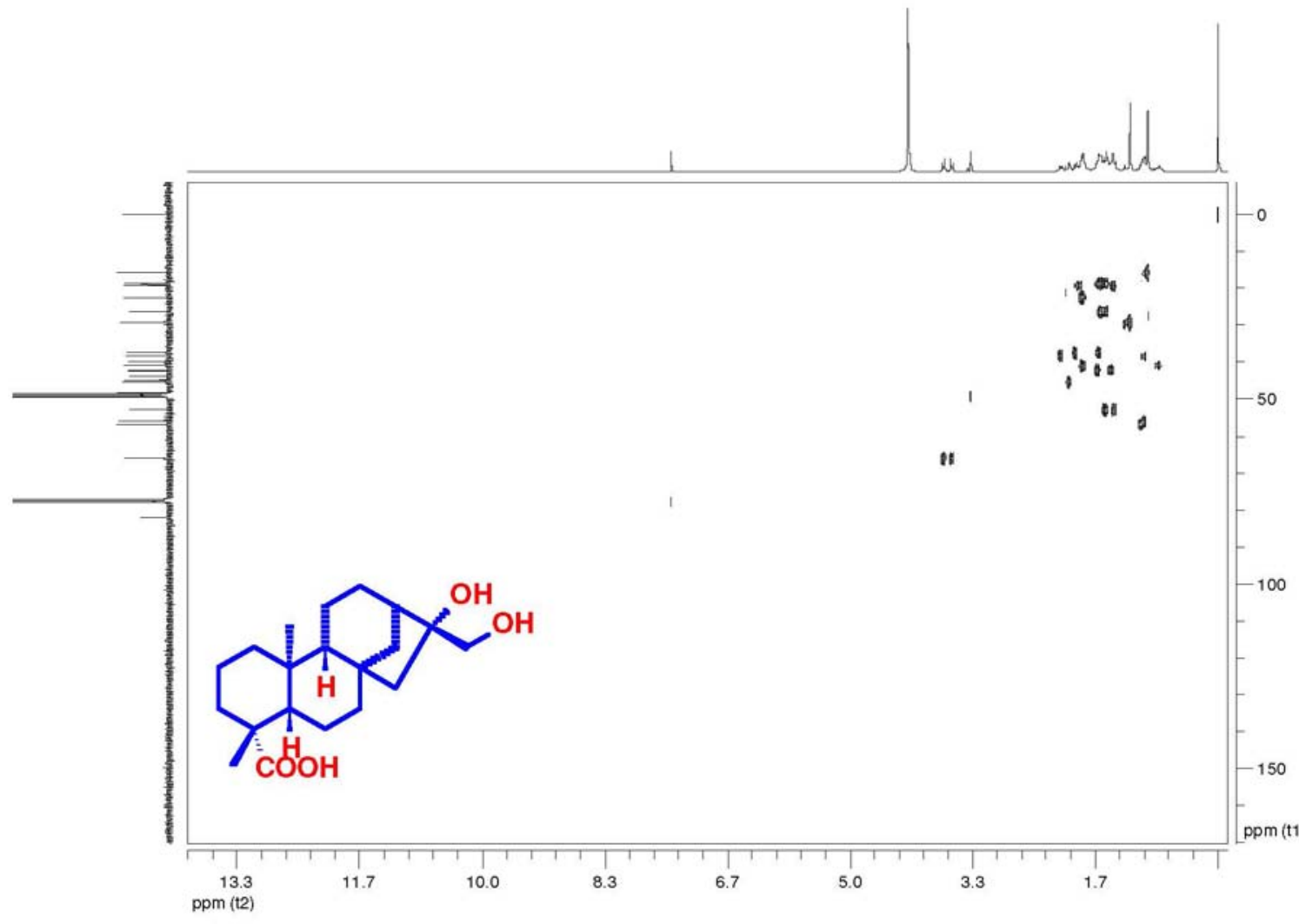

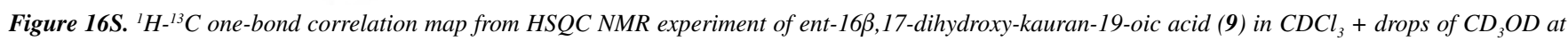
400 and $100 \mathrm{MHz}$ 


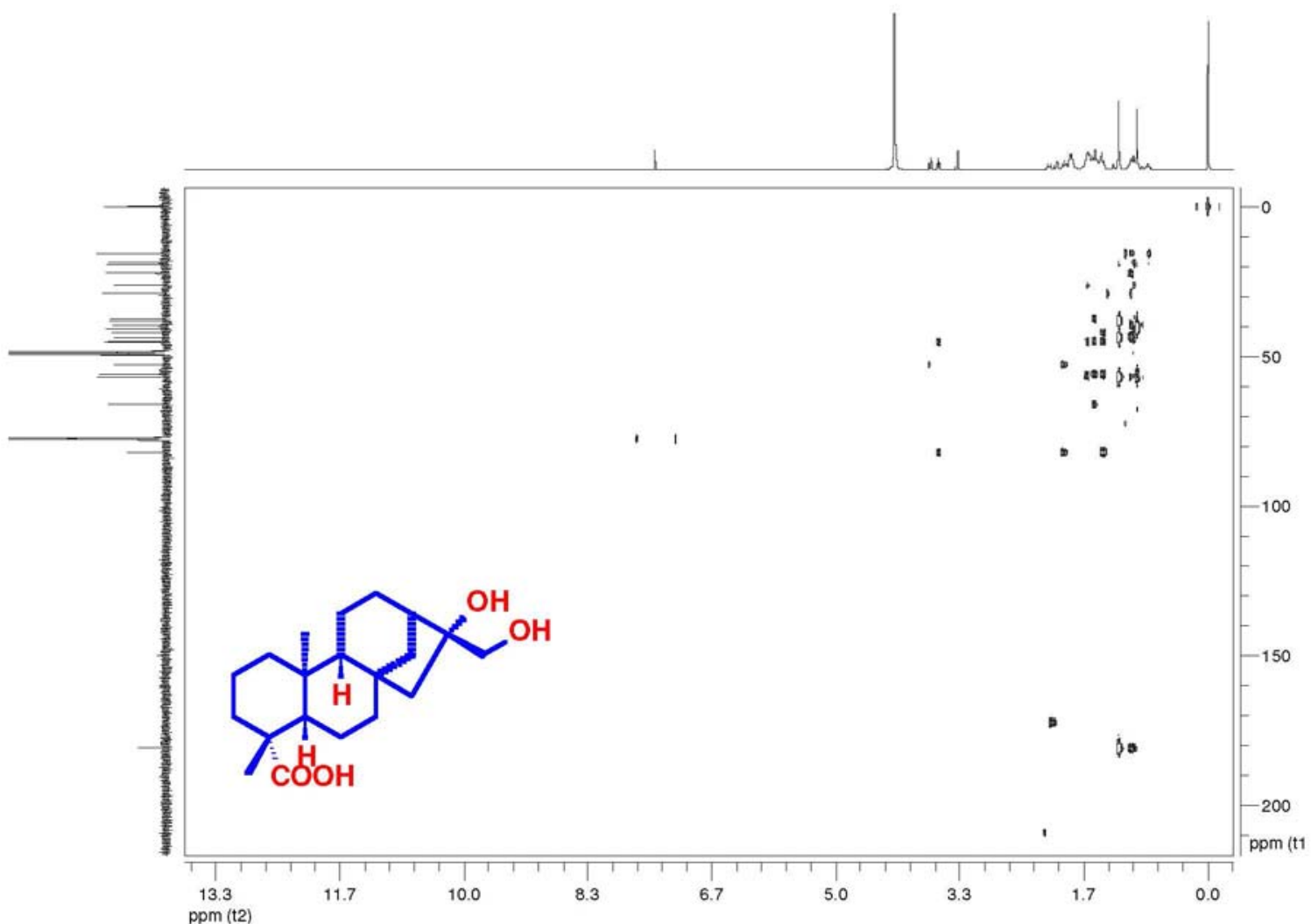

Figure 17S. ${ }^{1} \mathrm{H}-{ }^{13} \mathrm{C}$ long-range correlation map from $\mathrm{HMBC}$ NMR experiment of ent-16 $\beta, 17$-dihydroxy-kauran-19-oic acid (9) in $\mathrm{CDCl}_{3}+$ drops of $\mathrm{CD}_{3} \mathrm{OD}$ at 400 and $100 \mathrm{MHz}$ 